\title{
Review
}

\section{The Positive and Negative Immunoregulatory Role of B7 Family: Promising Novel Targets in Gastric Cancer Treatment}

\author{
Nadia Bolandi ${ }^{1,2}$, Afshin Derakhshani ${ }^{1,3}{ }^{(0}$, Nima Hemmat ${ }^{1}\left(\mathbb{D}\right.$, Amir Baghbanzadeh ${ }^{1}$, Zahra Asadzadeh ${ }^{1}$, \\ Mina Afrashteh Nour ${ }^{1,2}$, Oronzo Brunetti ${ }^{4}\left(\mathbb{D}\right.$, Renato Bernardini ${ }^{5}$, Nicola Silvestris $4,6, *,+(\mathbb{D})$ \\ and Behzad Baradaran $1,7,8, *,+(\mathbb{D}$
}

check for updates

Citation: Bolandi, N.; Derakhshani, A.; Hemmat, N.; Baghbanzadeh, A.; Asadzadeh, Z.; Afrashteh Nour, M.; Brunetti, O.; Bernardini, R.; Silvestris, N.; Baradaran, B. The Positive and Negative Immunoregulatory Role of B7 Family: Promising Novel Targets in Gastric Cancer Treatment. Int. J. Mol. Sci. 2021, 22, 10719. https:// doi.org/10.3390/ijms221910719

Academic Editor: Nam Deuk Kim

Received: 10 September 2021

Accepted: 1 October 2021

Published: 3 October 2021

Publisher's Note: MDPI stays neutral with regard to jurisdictional claims in published maps and institutional affiliations.

Copyright: (c) 2021 by the authors. Licensee MDPI, Basel, Switzerland. This article is an open access article distributed under the terms and conditions of the Creative Commons Attribution (CC BY) license (https:// creativecommons.org/licenses/by/ $4.0 /)$
1 Immunology Research Center, Tabriz University of Medical Sciences, Tabriz 516615731, Iran; nbolandi@yahoo.com (N.B.); afshin.derakhshani94@gmail.com (A.D.); nima.hemmat1995@gmail.com (N.H.); amirbaghbanzadeh@gmail.com (A.B.); Zahraasadzadeh2834@gmail.com (Z.A.); mina_afrashteh@yahoo.com (M.A.N.)

2 Department of Biochemistry, Faculty of Medicine, Urmia University of Medical Sciences, Urmia 571478334, Iran

3 Laboratory of Experimental Pharmacology, IRCCS Istituto Tumori Giovanni Paolo II, 70124 Bari, Italy

4 Medical Oncology Unit-IRCCS Istituto Tumori “Giovanni Paolo II" of Bari, 70124 Bari, Italy; dr.oronzo.brunetti1983@gmail.com

5 Department of Biomedical and Biotechnological Sciences, University of Catania, Via S. Sofia 97, 95100 Catania, Italy; bernardi@unict.it

6 Department of Biomedical Sciences and Human Oncology (DIMO), University of Bari, 70124 Bari, Italy

7 Department of Immunology, Faculty of Medicine, Tabriz University of Medical Sciences, Tabriz 516615731, Iran

8 Pharmaceutical Analysis Research Center, Tabriz University of Medical Sciences, Tabriz 516615731, Iran

* Correspondence: n.silvestris@oncologico.bari.it (N.S.); baradaranb@tbzmed.ac.ir (B.B.); Tel.: +98-413-3371440 (B.B.); Fax: +98-413-3371311 (B.B.)

+ Co-last authors.

Abstract: Gastric cancer (GC), with a heterogeneous nature, is the third leading cause of death worldwide. Over the past few decades, stable reductions in the incidence of GC have been observed. However, due to the poor response to common treatments and late diagnosis, this cancer is still considered one of the lethal cancers. Emerging methods such as immunotherapy with immune checkpoint inhibitors (ICIs) have transformed the landscape of treatment for GC patients. There are presently eleven known members of the B7 family as immune checkpoint molecules: B7-1 (CD80), B7-2 (CD86), B7-H1 (PD-L1, CD274), B7-DC (PDCD1LG2, PD-L2, CD273), B7-H2 (B7RP1, ICOS-L, CD275), B7-H3 (CD276), B7-H4 (B7x, B7S1, Vtcn1), B7-H5 (VISTA, Gi24, DD1 $\alpha$, Dies1 SISP1), B7-H6 (NCR3LG1), B7-H7 (HHLA2), and Ig-like domain-containing receptor 2 (ILDR2). Interaction of the B7 family of immune-regulatory ligands with the corresponding receptors resulted in the induction and inhibition of $\mathrm{T}$ cell responses by sending co-stimulatory and co-inhibitory signals, respectively. Manipulation of the signals provided by the B7 family has significant potential in the management of GC.

Keywords: B7 family; immune checkpoints; immunotherapy; gastric cancer

\section{Introduction}

Gastric cancer (GC) is classified as the third leading cancer in cancer-related mortality and the fifth most widespread malignancy worldwide. Based on GLOBOCAN 2018 data, the GC prevalence rate tends to be higher in East Asia compared to Western countries [1]. GC patients do not show any particular symptoms in the early stages of cancer, and diagnosis of GC is delayed. Therefore, although the mortality rate of GC has been declining in recent years, it is still considered life-threatening cancer [2]. The combination of some chemotherapy drugs, such as fluoropyrimidine with platinum base and irinotecan with taxane and surgical treatment, can be used as a standard option to treat patients with 
GC. However, the average survival rate of these patients is less than 10 months [3]. Immunotherapy is well studied as an efficient strategy for cancer therapy due to the induction of specific and long-lasting anti-cancer effects. Immunotherapy via ICIs is considered as a novel approach for cancer treatment and can prevent recurrence of tumors [4]. The immune system is frequently suppressed as tumors progress, interfering with a successful anti-tumor response. On the other hand, in autoimmune diseases, the immune system actively attacks and destroys the self-tissues. In order to elicit protective immunity against cancer and infection and inhibit the overactivity of the immune system, immune responses need to be strictly controlled by the B7 family members, which contain co-stimulatory and co-inhibitory molecules [5,6]. T cells are introduced as central elements of adaptive immunity, and their activation depends on two signals: signal 1, or antigen recognition, where peptides presented by the main histocompatibility complex (MHC) are identified by $\mathrm{T}$ cell receptors (TCRs), and signal 2, or co-stimulation, involving the combination of co-regulators such as $\mathrm{B} 7$ proteins, consisting of co-stimulatory and co-inhibitory molecules expressed on antigen-presenting cells (APC). Co-stimulation is balanced by co-inhibitory signals, which finally describe whether the T cell response is activating or inhibitory [7]. The B7 family is one of the most significant secondary signaling mechanisms and is vital in preserving the balance between immune potency and the suppression of autoimmunity [8]. At present, the growing $B 7$ family includes 11 members, which are B7-1 (CD80), B7-2 (CD86), B7-H1 (PD-L1, CD274), B7-DC (PDCD1LG2, PD-L2, CD273), B7-H2 (B7RP1, ICOS-L, CD275), B7-H3 (CD276), B7-H4 (B7x, B7S1, Vtcn1), B7-H5 (VISTA, Gi24, DD1 $\alpha$, Dies1 SISP1), B7-H6 (NCR3LG1), B7-H7 (HHLA2), and Ig-like domain-containing receptor 2 (ILDR2) $[7,9,10]$. It is reported that B7 molecules produce essential positive signals to start and support T-cell activity; moreover, they provide negative signals to regulate and stop T-cell reactions [11]. Additionally, the members of the B7 family appear as substantial elements in the regulation of tumor development, invasion, metastasis, and drug sensitivity, independent of the immune system [12]. Due to the operative function of ICIs in cancer treatment, the B7 family of molecules has extended remarkable consideration in recent years. In this review article, we describe the structure, expression, and function of the B7 family members. In addition, we focus on the role of the B7 family in humans' GC and the potential targeting of B7 family members with monoclonal antibodies, which is a promising strategy for GC treatment.

\section{B7-1 (CD80) and B7-2 (CD86)}

Two identified members of the B7 family proteins, B7-1 (CD80) and B7-2 (CD86), could bind to CD28 and Cytotoxic T-Lymphocyte Antigen 4 (CTLA-4) and act as their ligands (Figure 1, Table 1). B7-1/2 ligands with similar structures and approximately 25 percentage homologies are APC-related (type I) surface proteins [13]. Both B7-1 and B7-2 consist of one Ig variable-like $(\mathrm{IgV})$ domain and one Ig constant-like (IgC) domain. Despite their similar structure, B7-2 exists in the monomeric form on the surface of cells disparate from B7-1 [14]. B7-1 and B7-2 are expressed in dendritic cells, B/T cells, and APCs, and it is reported that the expression of B7-2 is up-regulated by APCs in stimulatory conditions [15,16]. B7-1 and B7-2 are different in the promotion and initiation of the T-cell responses. In this regard, the T-cell responses could be initiated and promoted by the expression of B7-2 and B7-1, correspondingly [16,17]. CTLA-4, the first-studied co-inhibitory molecule of the B7 family, was introduced as an initial receptor of the immune checkpoints [18]. CTLA-4 also defined CD152 as a homolog of CD28 (about 20 percent), sharing the identity of $30 \%$ and $27 \%$ of the level of amino acid in humans and murine, respectively. The structure of CTLA-4 includes domains and a leader peptide. These domains are the cytoplasmic tail, extracellular $\mathrm{V}$ domain, and ligand-binding domain, which have different numbers of amino acids [19]. CTLA-4/CD28 receptors are located on chromosome 1 at band C of mice, while they are located on chromosome 2 at bands q33-q34 of humans [20,21]. APCs, activated effector T-cells (Teffs), and regulatory T cells (Treg cells) express CTLA-4. Likewise, CTLA-4 is expressed on normal or neoplastic cells [22]. CD28 expression in humans occurs on 50\% 
and $80 \%$ of CD8+ and CD4+ T-cells (individually). Additionally, it is proved that CD28 expression takes place on various cells containing plasma cells, bone marrow stromal cells, and neutrophils [23]. The binding of CTLA-4/CD28 to CD80 or CD86 ligands occurs at the immunological synapse between antigen-presenting cells (APCs) and T cells [24]. According to studies, CD28 strongly binds to B7-2 while CTLA-4 has a higher binding affinity to both B7-1 and B7-2 $[25,26]$. The interaction of B7-1 and B7-2 ligands with CD28 delivers stimulation signals to immune response and induces survival of $\mathrm{T}$ lymphocytes. The interaction of CTLA- 4 with these ligands delivers inhibitory signals for activation of T-lymphocytes. It also results in decreased production of cytokines and immune responses against malignant tumors $[27,28]$. The inhibitory function of CTLA-4 is suppressed using humanized monoclonal antibodies such as ipilimumab and tremelimumab. These antiCTLA-4 antibodies have been accepted to manage cancers such as GC, non-small cell lung cancer (NSCLC), and melanoma [29,30]. It is demonstrated that transfection of B7-1 as a co-stimulatory factor induces an immunogenicity mechanism to suppress lymph node metastasis in GC. Moreover, it has been proven that the expression of B7-1 is decreased in GC and thus, increased expression of B7-1 on gastric GC cells decreases tumor growth. Therefore, B7-1, due to its anti-tumor functions, can be utilized in immunotherapy of GC [31,32]. Following previous findings, the prognostic role of B7-1 is detected in GC patients. It is indicated that B7-1 is expressed in low levels in the tissue of GC in comparison with normal gastric tissue. Moreover, it is reported that poor disease-free survival (DFS) and overall survival (OS) and immune evasion in GC result from the downregulation of B7-1. Thus, B7-1 might be considered an efficient target for GC therapy [33]. Interestingly, in contrast to the above results, Yang and colleagues reported that the protein levels of B7-1, B7-2, CTLA-4, and CD28 are broadly expressed in GC tissues compared to normal tissues adjacent to the tumors. They revealed that B7-1, B7-2, CTLA-4, and CD28 expression could induce tumor angiogenesis in GC by activating VEGF-A expression. Consequently, for assessing the biological behaviors, CD28, CTLA-4, B7-1, B7-2, and VEGF-A expression levels might be beneficial in GC [34].

Table 1. Classification of the B7 family ligands and their receptors.

\begin{tabular}{|c|c|c|c|}
\hline B7 Family Ligands & Alias Name & $\begin{array}{l}\text { Corresponding } \\
\text { Receptor(s) }\end{array}$ & Function \\
\hline B7-1 & CD80 & CD28/CTLA-4 & $\begin{array}{l}\text { Co-stimulatory/Co- } \\
\text { inhibitory }\end{array}$ \\
\hline B7-2 & CD86 & CD28/CTLA-4 & $\begin{array}{l}\text { Co-stimulatory/Co- } \\
\text { inhibitory }\end{array}$ \\
\hline B7-H1 & PD-L1/CD274 & PD-1(CD279)/CD80 & Co-inhibitory \\
\hline B7-DC & PD-L2/CD273 & PD-1 (CD279) & Co-inhibitory \\
\hline B7-H2 & ICOSL & $\mathrm{ICOS} / \mathrm{CD} 28$ & Co-stimulatory \\
\hline B7-H3 & CD276/B7RP-2 & TLT-2 (?) & $\begin{array}{l}\text { Co-stimulatory/Co- } \\
\text { inhibitory }\end{array}$ \\
\hline B7-H4 & B7S1/B7x & BTLA (?) & Co-inhibitory \\
\hline B7-H5 & VISTA/PD-1H & PSGL-1 (?) & Co-inhibitory \\
\hline B7-H6 & NCR3LG1 & NKp30 & Co-stimulatory \\
\hline B7-H7 & HHLA2 & CD28H/TMIGD2 & $\begin{array}{l}\text { Co-stimulatory/Co- } \\
\text { inhibitory }\end{array}$ \\
\hline ILDR2 & - & (?) & Co-inhibitory \\
\hline
\end{tabular}




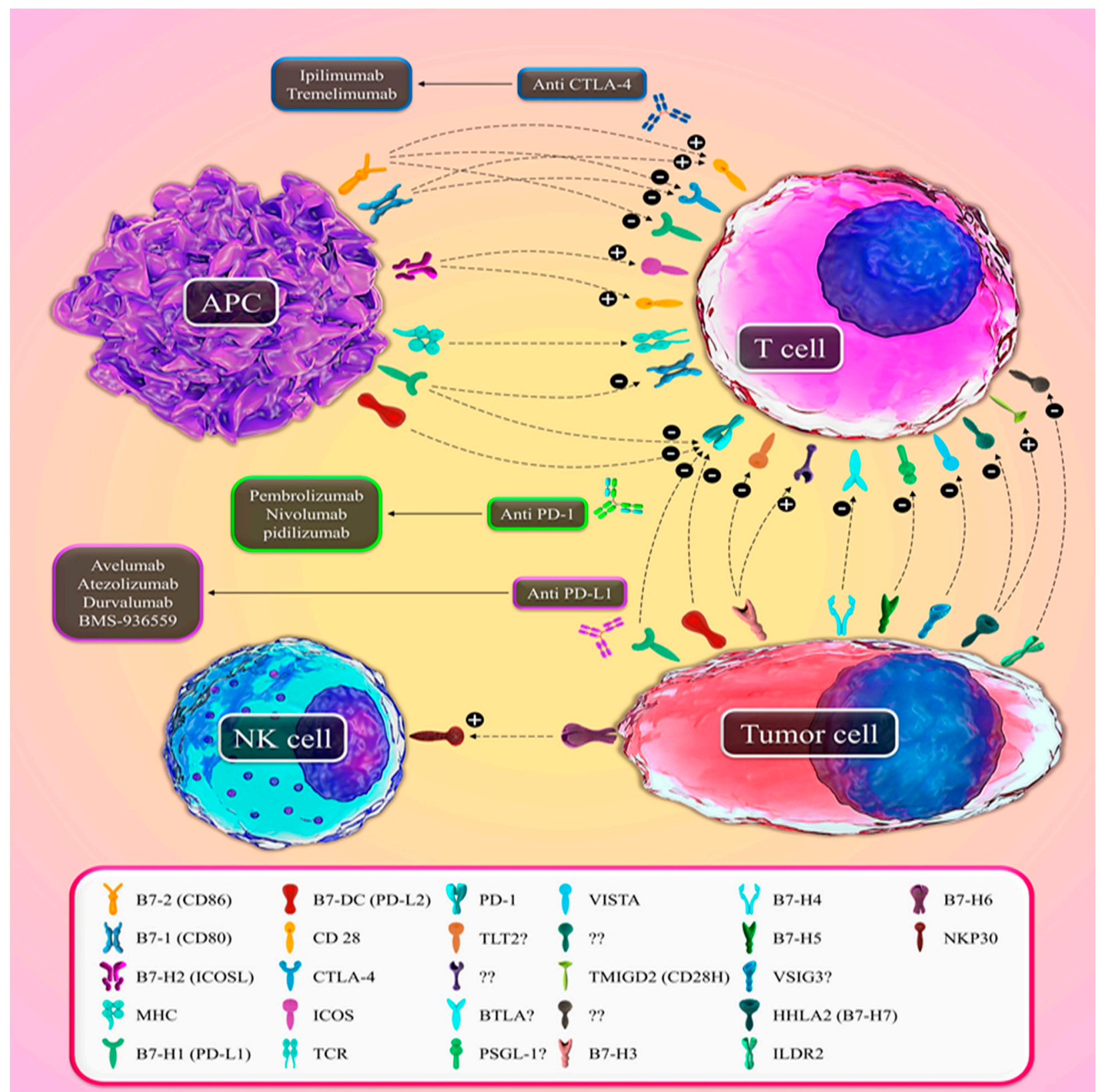

Figure 1. A suggested model for the functions of B7 family ligands with their cognate receptors. The interaction of the B7-1 and B7-2 with CD28, ICOSL with ICOS, and HHLA2 with TMIGD2 resulted in sending co-stimulatory signals. The interaction of NKP30 expressed in NK cells with B7-H6 expressed in tumor cells resulted in the activation of T cells or NK cells. The interaction of B7-1 and B7-2 with CTLA-4, PD-L1, and PD-L2 with PD-1, and PD-L1 with B7-1, provide co-inhibitory signals to stop T-cell reactions. The corresponding receptors that are generally accepted for B7-H3, B7-H4, B7-H5, and ILDR2 have not been reported.

\section{B7-H2 (ICOSL)}

The other co-stimulatory ligand that binds to the CD28 family is B7-H2, also known as ICOSL and B7h. ICOSL as B7 homolog binds not only to the Inducible Co-Stimulator (ICOS) but also to the CD28 in humans (Figure 1, Table 1) [35,36]. ICOSL consists of an IgV-IgC extracellular domain. The encoding gene of ICOSL is located on the 21st and 10th chromosomes in humans and mice, respectively. The encoding gene of ICOS with five exons is situated on chromosome 2q33-34 [37]. The engagement of CD28 and TCR resulted in ICOS induction, and positive co-stimulatory signals were delivered [38]. Even though the ICOS expression is boosted on activated T-lymphocytes, it is diminished by 
unstimulated naïve T-cells. Additionally, ICOSL is chiefly expressed by various cells of APCs such as endothelial cells, macrophages, non-hematopoietic cells, B-cells, monocytes, and dendritic cells, but is not expressed via innate lymphoid cells or T lymphocytes [39]. Moreover, ICOSL is expressed at low levels in some types of solid tumors such as glioma, colorectal cancer, and GC [40]. The expression of this ligand on endothelial cells enhances both the activation of CD8+ memory T-cell and co-stimulation of CD8+ T-cell [41,42]. ICOS and CD28 receptors have different roles in contrast to CTLA-4. These members of the B7 family, via competitive anti- and pro-inflammatory effects, regulate the immune system's response [43]. As a consequence of ICOSL and its relevant receptor interaction, the Bcl6 transcription factor is induced to form follicular helper T cells [44,45]. Activating T-cells requires the activation of phosphatidylinositol-3-kinase (PI3K), which correlates with signal transduction pathways and induces the Th2 pathway [46]. Additionally, depending on the cell type, these interactions have an increasing effect in the production of several $\mathrm{T}$ cell cytokines and an inhibitory effect on apoptosis by increasing the activity and function of intracellular molecules $[47,48]$. One of the essential mechanisms related to the ICOS/ICOSL pathway is the induction of anti-tumor response mechanisms such as stimulation of CD8+ $\mathrm{T}$ cell response [49]. In contradiction to this role, ICOS decreases anti-tumor immunity because of the increased function of Treg cells, mainly through the secretion of IL10 and TGF- $\beta$ [50]. Preliminary results from human trials of INDUCE-1 (NCT02723955), as an ICOS agonist antibody, showed that INDUCE-1 individually or in combination with PD-1 blocking antibodies such as pembrolizumab plays an essential role in cancer patients [51]. Nagase et al. demonstrated that ICOS+, Foxp3, and CD4+ T cells were plentifully found in tumor-infiltrating lymphocytes (TILs) in the end-stage of GC. They proved that ICOS expression in Foxp3 cells could be related to ICOSL, Helicobacter pylori infection, and TLR9 in plasmacytoid DCs (pDCs). The existence of the Helicobacter pylori antibody is a reason for considerable numbers of ICOS+ Foxp3+ cells in GC tissues. The results of their study demonstrated that immunotherapy agents, which target the ICOS checkpoint pathway and the eradication of Helicobacter pylori, are used as immunotherapy for GC [52]. Huang X-M et al. indicated that the number of ICOS+ Tregs is enhanced in peripheral blood (PB) of GC patients. There is a direct relation between ICOS+ Tregs number and illness severity. ICOS+ Tregs are generated from CD4+naïve T cells due to the increasing of pDCs number in GC. Therefore, $\mathrm{pDCs}$ and ICOS+ Tregs are involved in the suppression of immune response in GC [53]. MiR-24 has a leading role not only in regulating genes involved in various cancers but also in the oncogenesis of colorectal cancer, GC, etc. [54,55]. In this regard, Yang et al. demonstrated that miR-24 could regulate ICOSL expression. miR-24 also has an inhibitory effect on the expression of ICOSL by binding to the $3^{\prime}$-untranslated region ( $3^{\prime}$-UTR) of ICOSL. They found that single nucleotide polymorphisms (SNP) rs4819388, situated in the ICOSL 3'-UTR, disrupt the inhibitory effect of miR-24 on ISOSL expression. Consequently, SNP rs4819388 has an effective function in the progression of GC [56]. Therefore, targeting the ICOSL/ICOS pathway could be used to improve GC therapy.

\section{B7-H1 (PD-L1) and B7-DC (PD-L2)}

Programmed cell death-ligand 1 (PD-L1, also assigned as B7-H1 or CD274) and programmed cell death-ligand 2 (PD-L2, also assigned as B7-DC or CD273) are two ligands of programmed cell death 1 (PD-1, CD279) (Figure 1, Table 1) [57,58]. The PD-1 encoding gene is PDCD1 with five exons, while the PD-L1 encoding gene is CD274 with seven exons [59]. The amino acid sequence homology between PD-L1 and PD-L2 is approximately 40 percent $[60,61]$. The soluble PD-L1 (sPD-L1) is the other form of PD-L1, which is mostly found in sera of healthy people. It has also been discovered in various cell lines of cancer [59]. Both PD-L1 and PD-L2 consist of one IgV and one IgC domain. The PD-1 structure with two tyrosine base/288 amino acids includes a membrane-permeating domain, extracellular domain, and cytoplasmic tail at $C$ terminal [62]. Phosphorylation of PD-1 is accomplished in immunoreceptor tyrosine-based inhibitory motif (ITIM) and immunoreceptor tyrosine-based switch motif (ITSM). Accordingly, after PD-1 phosphoryla- 
tion, the TCR signal is regulated through Src homology 2 domain-containing phosphatase 1 (SHP1) and SHP2 [59]. The affinity of PD-L2 and PD-L1 is 3:1 to bind with their PD-1 receptor [63]. It has been demonstrated that PD-L1 binds to either PD-1 or B7-1 (CD80). The interaction of PD-L1/PD-L2 with PD-1 boosts tolerance of T-cells, induces an inhibitory effect on T-cell activation/proliferation, increases the conversion of Thelper cells into Foxp3+ Treg cells, and prevents cytolysis of T cell in cancerous cells. Consequently, it causes cancer growth and suppresses the immune system [64]. The interaction of PD-L1 with B7-1 (CD80) leads to a reduction in the production of cytokine and proliferation of T lymphocytes [65]. Expression of PD-1 occurs on the macrophages, natural killer cells (NK cells), T helper cells, cytotoxic T cells, dendritic cells, monocytes, B cells, and mainly on activated T lymphocytes [66]. The expression of PD-L1 individually in inflammatory situations is accomplished by epithelial cells, dendritic cells, activated T lymphocytes, macrophages, and B cells [67]. Moreover, it is prominently expressed in several cancers, such as gastric, multiple myeloma, renal cell carcinoma, melanoma, etc. However, PD-L2 expresses chiefly on APCs such as non-hematopoietic tissues, myeloid dendritic cells, and macrophages [66]. The result of a study revealed that the PD-L1 expression is enhanced through signaling pathways such as PI3K/Akt/mTOR. Moreover, they proved that immunoresistance mediated by PD-L1 could be suppressed by PI3K kinase pathway inhibitors [68]. High expression of PD-L1 inhibits anti-tumor immunity and increases chemoresistance in human cancers. In this regard, Wu et al. revealed that PD-L1 overexpression enhanced the ERK pathway activation in tumor cells. PD-L1 expression is also essential for P38 MAPK activation. It is noteworthy that activation of the ERK/P38 MAPK pathway depends on the association between the catalytic subunit of a DNA-dependent serine/threonine-protein kinase and PD-L1. Thus, the reason for cancer chemoresistance in tumor cells can be due to the above signaling pathways' activation [69]. Targeting the PD1/PD-L1 pathway via antibodies against them is one of the remarkable treatment strategies in different types of cancer. Particularly, pembrolizumab, nivolumab, and pidilizumab can target PD-1 while atezolizumab, durvalumab, avelumab, and BMS-936559, which are anti-PD-L1 antibodies [70]. According to a study, the suppression of PD-1/PD-L1 expression induces the expression of miR-21 in GC. It is also indicated that the Treg cell number decreased while the Th17 cell number enhanced. Hence, the study showed that miR-21 is negatively controlled by the PD-1 [71]. Zhang and colleagues concluded that PD-L1 is overexpressed at high levels in GC patients [72]. Furthermore, it is proved that in GC, activation of the hedgehog $(\mathrm{Hh})$ signaling increases the expression of PD-L1 and induces resistance in cancer immunotherapy. It is proposed that amelioration of therapeutics is possible through combination drug therapy with inhibition of immune checkpoints and Hh signaling in GC patients [73]. Geng et al. showed that PD-L1 was directly correlated with metastasis in lymph nodes, tumor depth of invasion, and Foxp3+ expression. They demonstrated that Foxp3+ and PD-L1 have a negative prognostic role in GC [74]. Moreover, Wang and colleagues demonstrated that PD-L1 could be overexpressed in GC due to somatic mutations, such as guanine allele to cytosine allele mutation at the $3^{\prime}$-untranslated region (3'-UTR) of the PD-L1. Moreover, miR-570 has a post-transcriptional regulatory and inhibitory role in PD-L1 expression. Mutation in PD-L1 3'-UTR disrupts the inhibitory role of miR-570 and decreases binding affinity to miR-570. Therefore, the level of miR-570 expression is reduced after overexpression of PD-L1 in GC [75]. Imai and colleagues showed that Interferon- $\gamma$ (IFN- $\gamma$ ) induced the expression of membranous and intracellular PD-L1 in GC cells. Additionally, a noticeably high concentration of sPD-L1 was observed not only in the GC patient's serum but also in the GC supernatant [76]. It has also been demonstrated that loss of heterozygosity ( $\mathrm{LOH}$ ) at the PTEN gene leading to PD-L1 represents a high level of expression in GC patients. GC with a mutation in the PIK3CA that causes PD-L1 is also considerably expressed [77,78]. Deng et al. indicated that expression of PD-L1 in GC considerably is associated with the expression of histone deacetylase 1 and 3; additionally, IFN- $\gamma$ can induce expression of PD-L1 in this cancer. They showed that the suppression of histone deacetylase decreased IFN- $\gamma$-induced PD-L1 expression. Thus, it is suggested 
that targeting the PD-L1 expression via small molecular inhibitors of histone deacetylase could be useful in GC therapy [79]. It is revealed that PD-L2 is expressed significantly in a special type of GC known as Epstein-Barr virus (EBV)-associated GC (EBVaGC) [80]. Nakayama et al. revealed that expression of PD-L2 is detected in 28.4 percent of tumor cells related to patients with GC. PD-L2 expression is increased through IFN- $\gamma$ in these patients. Furthermore, IL-4 induces the PD-L2 expression. Consequently, IFN- $\gamma$ and IL-4, due to the PD-L2 upregulation, can promote GC progression [81]. Using multicolor flow cytometry, SAITO and colleagues proposed that elevated levels of PD-L1 expression were observed on both CD4+ and CD8+ T cells in GC tissue. Additionally, they presented that a high level of PD-1 expression on CD4+ and CD8+ T cells can induce immune system evasion in GC patients [82]. Chang and colleagues found that higher levels of CD8+ tumorinfiltrating lymphocytes (TIL) from patients with gastric adenocarcinoma can be associated with a poor prognosis value of PD-L1 expression [83]. Another study demonstrated that PD-L1 expression is detected in the immune stromal and tumor cells of GC. They showed that enhancing infiltration of CD8 T lymphocytes is associated not only with a high level of PD-L1 expression but also with poor OS and progression-free survival (PFS) in these patients [84]. As a result, according to the studies mentioned above, the levels of PD-L1 and PD-L2 (especially PD-L1) are overexpressed in GC patients.

\section{B7-H3 (CD276)}

B7-homolog 3 protein (B7-H3; also termed CD276 and B7 relative protein 2 (B7RP-2)) is recognized as a $45-66 \mathrm{kDa}$ transmembrane glycoprotein (type I) in the B7 family immune checkpoints. B7-H3 with ten exons shares about $20-27 \%$ of identical amino acid sequences with other B7 family members. Initially, B7-H3 was defined in humans and later in mice. The B7-H3 gene is situated on chromosomes 15 and 9 in humans and mice, respectively $[85,86]$. The B7-H3 extracellular domain is composed of two similar pairs of the $\mathrm{IgV}$ and $\mathrm{IgC}$ domains (VCVC) in humans because of duplication of the exon, but in mice, it consists of one $\operatorname{IgC}$ and one $\operatorname{IgV}$ domain. Extracellular $\operatorname{IgV}-\operatorname{IgC}$ domains are encoded through exons 4-7 of the B7-H3 gene [85]. The expression of B7-H3 mRNA is so broad that it is expressed on numerous cell types and tissues. Likewise, it is ubiquitously detected in both the nonlymphoid and lymphoid organs. However, protein expression is not only infrequent and at low levels but also significantly limited to cell types such as NK cells, B cells, T cells, monocytes, and activated DCs [87]. B7-H3 can be expressed considerably in several cancers such as breast, stomach, colorectum, lung, etc. [88]. Analysis of the association between miR-29 and B7-H3 expression revealed that the low expression rate of miR-29 induces overexpression of B7-H3 in tumor tissue. MiR-29 not only has a modulatory role in the B7-H3 expression level in cultured cell lines but also targets B7-H3 mRNA [89]. It was demonstrated that B7-H3 has a co-stimulatory role i CD4 and CD8 T cell proliferation in the presence of an anti-CD3 antibody.B7-H3 also enhances cellular immune responses and IFN- $\gamma$ generation in the presence of TCR signaling [86]. In comparison to the co-stimulatory role of $\mathrm{B} 7-\mathrm{H} 3$, most studies have generally shown that $\mathrm{B} 7-\mathrm{H} 3$ predominantly has a negative regulating role on $\mathrm{T}$ lymphocytes in humans and murine $[90,91]$. Moreover, B7-H3 inhibits the proliferation of T helper cells and cytotoxic $\mathrm{T}$ cells and decreases the production of IL-2 and IFN $\gamma$ [90]. It is suggested that B7-H3 expression suppresses $\mathrm{T}$ cell activity by inhibiting or moderating transcription factors such as a nuclear factor of activated T cells (NFAT), AP-1, and NF- $K \beta$ [92]. Likewise, Veenstra et al. presented acceptable proof that $\mathrm{B} 7-\mathrm{H} 3$ is considered a co-inhibitory molecule and reduces activation of $\mathrm{T}$ cells [93]. It was also shown that B7-H3 suppresses the function of NK cells and induces mineralization in bone tissues and differentiation of osteoblast [94,95]. Collectively, B7-H3 can function as a co-stimulatory and co-inhibitory molecule; the difference in its role could be related to the existence of different immune cells/cytokines and multiple unidentified binding partners (Figure 1, Table 1) [6]. Triggering receptor expressed on myeloid cells (TREM)-like transcript 2 (TLT-2, TREML2) has been reported as a murine B7-H3 receptor which is generally accepted by most studies [96]. Some studies did not find 
proof of the presence of an interaction between B7-H3 and TLT-2. They proved that TLT2 is not considered as a corresponding receptor for $\mathrm{B} 7-\mathrm{H} 3[97,98]$. To date, the putative receptor as a binding partner for B7-H3 remains uncertain [99]. In this regard, the result of a study revealed that an anti-B7-H3 monoclonal antibody such as humanized $8 \mathrm{H} 9$ could suppress the inhibitory effect of B7-H3 in humans through binding to the FG loop [100]. Another monoclonal antibody ( $\mathrm{mAb}$ ) against B7-H3 is enoblituzumab (MGA271), which inhibits the development of tumors [101]. Wu and co-workers demonstrated that the B7-H3 expression is detected in $58.8 \%$ of GC samples and in all gastric adenoma samples. They reported that patients with GC who have low levels of B7-H3 expression have a survival rate that is half that of patients with high levels of B7-H3 expression. B7-H3 expression is associated not only with survival in GC patients but also with tumor infiltration depth. A low level of B7-H3 expression causes the tumor to escape the immune system. Therefore, the level of B7-H3 expression is a good indicator for the prognosis and diagnosis of GC patients [102]. Furthermore, it was indicated that B7-H3 is considerably expressed in GC patients in comparison with the normal gastric group. They showed that in an orthotopic transplantation GC model, suppression of B7-H3 via RNA interference reduces metastasis such as invasiveness and migration in vitro and in vivo. Thus, $\mathrm{B} 7-\mathrm{H} 3$ might have a main function in the regulation of GC metastasis [103]. It has also been demonstrated that enhanced expression of $\mathrm{B} 7-\mathrm{H} 3$ is associated with the CXCR4 expression and tumor infiltration depth in GC patients. Additionally, the ability of cell migration and invasion in GC is reduced by suppressing B7-H3 by shRNA and decreasing the activity of signaling pathways such as Jak2/Stat3, ERK, and AKT in the GC cells [104]. Furthermore, overexpression of B7-H3 and activated phenotype of CD54+ has been detected on neutrophils in GC tumors, which is directly related to the detection of granulocyte-macrophage colony-stimulating factor (GM-CSF). Therefore, GM-CSF-activated neutrophils express B7-H3 that resulted in tumor aggressiveness in human GC by activation of the JAK-STAT3 signaling pathway [105]. Recently, Zhan and colleagues indicated that B7-H3 expression is remarkably observed in stromal and tumor cells of gastric adenocarcinomas (GACs); also, a high level of stromal B7-H3 expression is correlated with high expression of alpha-smooth muscle actin protein in these patients. They showed that inhibition of B7-H3 via small interfering RNA leads to reducing the potency of invasion and migration in cancer-associated fibroblasts (CAFs) and suppression of cytokine secretion. Therefore, elevated expression of B7-H3 might serve as a poor prognosis indicator for patients with GACs [106]. It is demonstrated that expression of B7-H3 can induce radiotherapy resistance of GC cells via modulating DNA double-strand break repair, cell cycle, and apoptosis. Moreover, cell autophagy baseline levels are regulated by B7-H3 in GC tissue, indicating that radioresistance in GC cells is caused by the expression of B7-H3 via regulation of cell autophagy baseline levels [107]. By immunohistochemistry and analysis of the digital image, Ulase et al. demonstrated that B7-H3 is expressed chiefly in the stromal compartment of patients with GC, and CD8+ $\mathrm{T}$ lymphocytes are inhibited in tumors with excessive expression of B7-H3. As a result, they reported that B7-H3, as a considerable target of GC immunotherapy, can regulate cell-mediated immunity responses in patients of Western origin [108]. Accordingly, the findings of various studies demonstrated that expression of B7-H3 is increased in GC patients.

\section{B7-H4 (B7x)}

B7 homolog 4 (B7-H4), also named-B7x and B7S1, belongs to the immune checkpoints of the B7 family. B7-H4 is a transmembrane protein, and the DNA sequence homology of this immune checkpoint with other B7 family members resulted in its identification in 2003. The encoding gene related to B7-H4 is VTCN1, which encodes 282 and 283 amino acids in humans and murine, respectively $[109,110]$. Structurally, B7-H4 consists of the intracellular domain, a hydrophobic transmembrane domain, and an extracellular domain [111]. B7-H4 consists of one $\mathrm{IgV}$ and one $\mathrm{IgC}$ domain. It is situated on chromosomes 3 and 1 in murine and humans, respectively [112]. B7-H4 is an inhibitory member of immunoregulatory 
molecules that do not bind to the CTLA4/CD28, ICOS, and PD-1 (Figure 1, Table 1) [110]. To date, a specific receptor for binding to $\mathrm{B} 7-\mathrm{H} 4$ has not been recognized; however, $\mathrm{B}$ and $\mathrm{T}$ lymphocyte attenuator (BTLA) was suggested as a B7-H4 receptor that binds indirectly, while further experiments have not accepted this proffer [113,114]. B7-H4 mRNA can be expressed in human renal cell carcinoma, GC, and ovarian cancer. B7-H4 is also discovered in the peripheral blood (PB) and tumor microenvironment (TME) [115]. It is proved that B7$\mathrm{H} 4$ has low expression in normal tissues [112]. The flow cytometric analysis demonstrated that B7-H4 does not express on the surface of dendritic cells, monocytes, and B/T cells in humans. However, the expression of B7-H4 in vitro could be moderately increased on such cells following stimulation with ionomycin, IFN- $\gamma$, phorbol 12-myristate 13-acetate, phytohemagglutinin, and lipopolysaccharides (LPS) [110]. Some studies have indicated that modification of B7-H4 expression depends on cytokines. For example, IL-10 and IL-6 increase the expression of B7-H4; however, IL-4 and DC-differentiation cytokines reduce their expression [116,117]. In this regard, Kryczek and colleagues have suggested that Treg cells stimulate the macrophages to generate IL10 and IL6. Thus, B7-H4 can be upregulated and inhibits $\mathrm{T}$ cell proliferation [118]. Contradictory results have been presented regarding the B7-H4 antitumor immunity by using various samples of mouse tumors and diversity in B7-H4 expressing cell types. In 2015, a study indicated that B7-H4 is necessary for antitumor immune responses and inhibits the development of tumors [119], while most studies have proved that $\mathrm{B} 7-\mathrm{H} 4$ has a negative modulatory role in $\mathrm{T}$ cell antitumor immune responses [112]. Previous studies have proved that recombinant antiB7-H4 antibodies are a possible strategy for improving anti-tumor immunity and inducing T-cell response [120,121]. Recently, Zhou et al. have revealed that B7-H4 expression in tumor cells of mouse models not only decreased the production of IFN- $\gamma$ but also negatively regulated CD8 tumor-specific T cell cytotoxicity, expansion, and activation. Consequently, $\mathrm{B} 7-\mathrm{H} 4$ overexpression leads to tumor growth and weakens tumor immunity in the mouse tumor model [122]. Arigami and co-workers proved that a high level of B7-H4 mRNA expression was detected in the peripheral blood lymphocytes (PBLs) of GC patients but not in normal PBLs from healthy volunteers. They realized that B7-H4 expression is a helpful factor for predicting GC progression and prognosis [115]. In addition, Jiang and colleagues demonstrated that the B7-H4 expression in GC patients was remarkably higher than tissues with a gastric polyp and epithelial of normal gastritis. They also indicated that B7-H4 induces metastasis of nodal and invasion of tumors in GC and revealed that B7-H4 has a prognostic marker value for GC [123]. It is also indicated that poor survival of GC patients in the advanced stage is the result of the development of neutrophils in the environment of GC. Moreover, GM-CSF stimulates neutrophils and increases the expression of B7-H4 via activation of JAK/STAT signaling. The result of this study revealed a new modulating mechanism of B7-H4 expression on neutrophils that can activate tumors in GC, proposing that efficient suppression of these new GM-CSF-B7-H4 pathways could be an appropriate strategy in GC therapy [124]. In another study, Geng et al. indicated that B7-H4 was directly associated with the expression of Foxp3+ and lymph node metastasis. They presented that low Foxp3+ expression is associated with better survival of GC patients [74]. Furthermore, the result of a meta-analysis study in 2016 showed that blood B7-H4 is an indicator of poor prognosis in GC patients [125]. It was proved that the inhibition of B7-H4 via siRNA not only reduces carcinogenesis of the MGC-803 human GC cell line but also increases apoptosis [126]. It has been revealed that the number of tumor-infiltrating lymphocytes (TIL), as indicators of good outcome of survival, is reduced in GC patients with overexpression of B7-H4 [127]. It is also indicated that neoadjuvant chemotherapy (NACT) of GC patients induces the presence of high CD4+ and CD8+ TIL levels and reduces the expression of $\mathrm{B} 7-\mathrm{H} 4$. Thus, downregulation of $\mathrm{B} 7-\mathrm{H} 4$ might be considered as a proper biomarker for response prediction of NACT in GC patients [128]. Consequently, the expression of $\mathrm{B} 7-\mathrm{H} 4$ as a prognostic factor can be considered an attractive target for GC therapy. 


\section{B7-H5 (VISTA)}

The presence of another molecule of the B7/CD28 superfamily, V-domain immunoglobulin suppressor of T cell activation (VISTA; also called B7-H5, PD-1 homolog (PD-1H), DD1 $\alpha$, Dies1, SISP1, and Gi24), has been recently reported, which can be a potential target in immuno-oncology $[129,130]$. VISTA is a well-defined type I immunoglobulin membrane protein with 279 amino acids, including cytoplasmic tail (96 amino acid residues), transmembrane domain (TMD) (21 amino acid residues), and extracellular domain (162 amino acid residues). The extracellular domain related to VISTA with homology to PD-1 and IgV-like domain of PD-L1 contains only one IgV domain $[129,131]$. The encoding gene of VISTA is Vsir, which is not only situated on chromosome 10 at a distant position from all members of the immunoglobulin superfamily but also is located within the intron of the $\mathrm{CDH} 23$ gene. Sequencing analysis of the VISTA gene disclosed that VISTA remarkably has a high level of conservation among members of the B7 family and represents 76 percent homology between humans and mice [132]. The expression of VISTA primarily but not particularly was detected in tissues that have considerable numbers of leukocytes and hematopoietic tissues. VISTA is overexpressed in myeloid cells and is associated with a reduced expression on CD4+ and CD8+ T lymphocytes. VISTA can be expressed at a high level on forkhead box protein 3 (FoxP3) + T regulatory cells and naive CD4+ T lymphocytes. VISTA represents low levels of expression on CD8+ T lymphocytes and NK (CD56hi) cells. Although there was no detectable VISTA expression on B cells, its expression has been reported considerably on plasma cells [133-135]. Previous studies revealed that VISTA could be expressed in human cancerous tissues such as colorectal cancer, GC, non-small cell lung cancer, pancreatic, ovarian cancer, prostate cancer, hepatocellular carcinoma, acute myeloid leukemia, and metastatic melanoma [135]. The expression of VISTA is upregulated through the enhancement of transcription factors such as hypoxia-inducible factor 1-alpha (HIF-1 $\alpha$ ) and p53 [136,137]. Deng et al., using chromatin immunoprecipitation, demonstrated that HIF- $1 \alpha$ could induce VISTA on myeloid cells in the tumor microenvironment (TME) and hypoxic situations [137]. VISTA participates in the controlling of immune system reactions due to possessing the main homeostatic role. This function of VISTA is the result of a specific and wide pattern of its expression. Therefore, there is discrimination between VISTA and other immunomodulatory receptors [138]. It is proved that VISTA acts as a co-inhibitory ligand on APCs, while it acts as a co-inhibitory receptor when expressed on CD4+ T lymphocytes. The proliferation and production of IFN- $\gamma$ and IL-2 are suppressed due to the VISTA expression on APCs. The expression of VISTA on CD4+ T lymphocytes resulted in the suppression of T cells $[133,139,140]$. In 2019, Wang et al. indicated that VISTA could act as a receptor. They demonstrated that the V-Set and Immunoglobulin domain containing 3 (VSIG-3) could be introduced as a new ligand partner for the VISTA. To date, the biological importance of VSIG-3/VISTA engagement is not identified. The interaction of VSIG-3 with VISTA as ligand receptors resulted in sending the co-inhibitory signals for the suppression of cytokine/chemokine production and the function of Tlymphocytes, in vitro [141]. Another study in 2019 demonstrated that VISTA is a ligand and P-selectin glycoprotein ligand-1(PSGL-1) is a receptor for VISTA. The researchers presented that engagement of PSGL-1 with VISTA takes place in acidic environments [142]. Collectively, VISTA is considered both as a ligand and receptor and has a co-inhibitory function (Figure 1, Table 1) [139]. In mouse tumor models, LeMercier et al. presented that using monoclonal antibodies against VISTA resulted in reduced an inhibitory function of VISTA and the number of tumor-associated FoxP3+ CD4+ Tregs. On the other hand, blocking the VISTA pathway induced the activity of intratumoral T lymphocytes. Hence, anti-VISTA antibodies increase the immune response to tumors, production of IFN $\gamma / \mathrm{TNF} \alpha$, and expression of CD44. Consequently, VISTA represents a promising novel target for immunotherapy of cancer, either on its own or in combination with another immune checkpoint blockade [133]. A recent study indicated that combination therapy of anti-VISTA and anti-PD-1 antibodies is efficient in mouse tumor models and may be an optimal option for treating cancers [143]. The outcome of combination immunotherapy using anti-VISTA 
plus anti-PD-L1 or anti-PD-1 antibodies increased TNF $\alpha, \operatorname{IFN} \gamma$, and serine protease such as granzyme $B(\mathrm{GrzB})$ in CD8+ T lymphocytes and decreased the tumor growth [129]. Hu and co-workers revealed that VISTA is overexpressed not only in the nucleus but also in the cytoplasm of GC patients' tissues. They showed an inverse correlation between OS rate and cytoplasmic VISTA expression at a high level in GC patients. In contrast, the five-year OS rate in GC patients with high nucleus VISTA expression is identical with GC patients, who have a low level of nucleus VISTA expression [144]. Oliveira et al. revealed that the expression of VISTA is reduced in GC cell lines compared to normal gastric tissue through the methylation of promoter-like methylation of CpG sites at the $5^{\prime}$ end of the Vsir gene and/or overexpression of miR-125a-5p [145]. Boger and colleagues, using immunohistochemistry, demonstrated that the VISTA expression in immune and tumor cells was observed in 83.6 and 8.8 percent of patients with GCs, respectively. The VISTA expression of immune cells remarkably is augmented from tumor grade pT1 to pT2, but reduced from $\mathrm{pT} 2$ to $\mathrm{pT} 3$. A change in VISTA expression was detected in tumors during the progression of GC. Moreover, researchers presented that the expression of VISTA in GC is correlated not only with PD-L1 expression but also with Epstein-Barr virus infection, tumor localization, Lauren phenotype, and KRAS-and PIK3CA-mutational status, while no correlation exists between the expression of VISTA with tumor stage, distant metastasis, and lymph node metastasis. Consequently, the predictive role of VISTA expression as a biomarker has not been assessed in patients with GC, and more research is required in this regard [146].

\section{B7-H6 (NCR3LG1)}

The B7 homolog 6 (B7-H6), also named NCR3LG1, belongs to the immune checkpoints of the B7 family and functions as an endogenous/co-stimulatory ligand. In 2009, Brandt's study using techniques such as mass spectrometry and bioinformatics resulted in detecting B7-H6 as a type 1 transmembrane protein [147]. The corresponding receptor of B7-H6 is NKp30, which is a natural killer (NK) cell-activating receptor (Figure 1, Table 1) [148]. It is reported that the extracellular region of NKp30 contains one IgV-like domain while the extracellular region of B7-H6 comprises IgV/IgC-like domains. B7-H6 intracytoplasmic domain includes $\mathrm{SH} 2 / \mathrm{SH} 3$-binding motif and Immunoreceptor tyrosine-based inhibitory motif (ITIM) [149]. It is revealed that the gene sequence of B7-H6 is homologous to PDL1 and B7-H3 [147]. On tumor cells, the binding of B7-H6 to NKp30, which is located on NK cells, induces the function of NK cells to identify tumors through the production of interferon- $\gamma$. Therefore, B7-H6 acts as an alarm system to alert innate immune responses [148]. Moreover, B7-H6 mRNA and protein expression are seen in different kinds of tumor cell lines, B/T cell lymphoma, and leukemia, but are absent in healthy peripheral blood mononuclear cells (PBMCs) or normal human tissue. Th expression of B7-H6 at high levels is detected in several types of cancer including breast cancer, lung cancer, melanoma, liver cancer, ovarian cancer, renal cell carcinoma, hepatocellular carcinoma, cervical carcinomas, brain cancer, and GC [147]. Matta and colleagues showed that B7-H6 is chiefly expressed at the neutrophils and pro-inflammatory CD14+ CD16+ monocytes surface. It is proved that activated neutrophils and monocytes can release soluble B7-H6. they also realized that IL-1 $\beta$ and tumor necrosis factor- $\alpha$ (TNF- $\alpha$ ), as well as toll-like receptor (TLR) ligands, can induce expression of B7-H6 [150]. Both immunological and non-immunological functions of B7-H6 are involved in tumorigenesis. It has been demonstrated that $\mathrm{B} 7-\mathrm{H} 6$ has an anti-apoptotic role and the initiation of caspase cascades is inhibited via B7-H6. Therefore, B7-H6 can increase tumorigenesis in tumor cells through the activation of a transcription factor such as the STAT3 signaling pathway [151]. Moreover, activation of apoptosis inhibitors through the STAT3 pathway causes that B7-H6 induces proliferation in tumor cells [152,153]. Additionally, it is revealed that the immunological role of B7-H6-induced tumorigenesis by IFN- $\gamma /$ TNF- $\alpha$ secretion and control of bi-specific T-cell engagers (BiTEs) triggers T cell cytotoxicity [154]. As B7-H6 is expressed in various types of cancer, it is a good candidate for targeted therapy, and using specific monoclonal 
antibodies against B7-H6 has been considered as a promising treatment of tumors [155]. It is revealed that mouse single-chain variable fragment $(\mathrm{scFv})$-based chimeric antigen receptors (CARs) can increase the anti-tumor function of T cells by targeting B7-H6 [156]. Chen et al., using immunohistochemistry, showed that the prognostic role of B7-H6 was not observed in GC patients. They realized that the B7-H6 expression is the same between gastric tumors and non-tumor adjacent tissue. No relevance was seen between the expression of B7-H6 and clinical features such as sex, age, distant metastasis, histological classification, lymph node metastasis, tumor size, and TNM stage. However, they demonstrated that a high degree of tumor differentiation is considerably associated with the positive expression of B7-H6 in gastric tumors [157]. On the other hand, in contrast to the above result regarding the predictive role of B7-H6 in patients with GC, it is demonstrated that a considerably high level of B7-H6 expression is a good predictor of OS for GC patients [158]. Hence, more research is required to recognize the prognostic value of B7-H6 in GC.

\section{B7-H7 (HHLA2)}

HHLA2 is an abbreviation form of the human endogenous retro virus- $H$ long terminal repeat associating-2, also named B7-H7 and B7y [159]. Screening in sequences of expressed genes (expressed sequence tags; ESTs) resulted in HHLA2 identification in 1999 [160]. Afterward, HHLA2 was detected as a member of the B7 ligand family. HHLA2 shares about $23-33 \%$ of similar amino acid sequences with other B7 family members. HHLA2 contains two Ig variable-like (IgV) domains and one Ig constant-like (IgC) domain (IgVIgC-IgV) [161,162]. According to a study by Zhu and colleagues, B7-H7 was before named B7-H5. However, at present, B7-H7 and B7-H5 are referred to as HHLA2 and PD-1H, respectively [161,163]. HHLA2 is found in humans but not in mice [164]. Zhu et al., through receptor array screening, indicated that $\mathrm{CD} 28$ homolog $(\mathrm{CD} 28 \mathrm{H})$ as a receptor could interact with HHLA2 on APCs [163]. Then, Janakiram et al. demonstrated that transmembrane and immunoglobulin domain-containing 2 (TMIGD2) could bind to humans HHLA2. TMIGD2 as a receptor is situated on chromosome 19q13.3 [165]. Sequencing analysis discloses that TMIGD2 and CD28H are similar molecules. Consequently, TMIGD2/CD28H are now considered as HHLA2 receptors [159]. This receptor-ligand interaction takes place on the different subsets of main immune cells such as CD4/CD8 T lymphocytes, and APCs (dendritic cells, B cells, monocytes) [161]. Previously, Janakiram et al., using immunohistochemistry, showed that the HHLA2 expression was seen not only in the epithelium of the breast, gallbladder, gut, and kidney, but also in trophoblastic cells of the placenta [159]. In the immune system of humans, HHLA2 represents high levels of expression on macrophages and monocytes, while there is no detectable HHLA2 expression on resting B or T cells and immature dendritic cells (DCs). Expression of HHLA2 at high levels also is detected in various types of cancer. In addition, expression of HHLA2 is induced on B lymphocytes and increased on the monocytes, and mature DCs subsequent stimulation with inflammatory signals such as poly I: C, IFN- $\gamma$, and lipopolysaccharide (LPS) $[161,163,164]$. Zhu et al. indicated that HHLA2 has a co-stimulatory role when it binds to the CD28H receptor on APCs. Consequently, the proliferation of T lymphocytes and cytokine production is increased through the AKT pathway [163]. In contrast to the costimulatory role of HHLA2, it has a co-inhibitory effect on the responses of T lymphocytes. The proliferation of CD4+ and CD8+ T lymphocytes is suppressed via HHLA2 in the existence of TCR signaling. The production of cytokine-like IFN $\gamma$, TNF $\alpha$, IL-5, IL-10, IL-13, IL-17a, and IL-22 is considerably decreased by incubating T lymphocytes with HHLA2 [161]. Collectively, HHLA2, like B7-H3, has co-stimulatory also co-inhibitory function on T lymphocytes in various situations (Figure 1, Table 1) [161,163]. The broad expression pattern of HHLA2 showed that HHLA2 has a role in developing tumors by inhibiting anti-tumor immune responses. Interestingly, the HHLA2 pathway is considered an appropriate target for cancer immunotherapy using ICIs and treatment with antibodydrug conjugates (ADCs) [159]. Targeting HHLA2 resulted in increased immune responses against tumors and the angiogenesis of tumors being suppressed [165]. Shimonosono and 
colleagues, using immunohistochemistry, examined the level of HHLA2 expression in the blood samples of GC patients and healthy people. It has been shown that normal epithelial cells expressed the highest level of HHLA2 compared with tumor cells. The researchers presented that the level of HHLA2 mRNA expression in blood samples of patients with GC is considerably lower than in peripheral blood mononuclear cell (PBMC) samples of healthy people. They also found that expression of HHLA2 at a low level resulted in tumor aggressiveness, adverse prognosis, as well as a lower five-year survival rate in GC patients. A low level of HHLA2 mRNA expression correlates with disease stage, distant metastasis, and tumor invasion depth in the blood of patients with GC. Consequently, the evaluation of HHLA2 expression in blood samples might be used not only to distinguish healthy people from GC patients but also to prognosticate the aggressiveness of GC [166]. On the other hand, in contrast to the above results regarding the prognosis of patients with GC, Wei et al., using two techniques such as immunohistochemistry and qRT-PCR, demonstrated that both the protein and mRNA expression HHLA2 are increased in the tissue of GC in comparison with normal gastric tissue. They concluded that overexpression of HHLA2 is correlated with poor OS outcomes. Therefore, patients with GC have lower OS due to higher expression levels of HHLA2 compared to those of patients with low expression of HHLA2. The HHLA2 expression at high levels is correlated with the presence of distant metastasis, metastasis in lymph nodes, deep tumor invasion, and advanced clinical-stage, while no considerable correlation exists between the expression of HHLA2 with the location of the tumor, age, gender, the histologic tumor grade, and Lauren's classification in GC patients. Consequently, overexpression of HHLA2 is considered not only as a remarkable risk factor for the malignant status of GC tissue but also as a biomarker of undesirable prognostic for OS in GC patients [167]. It is noteworthy that the difference between Shimonosono et al.'s and Wei et al.'s results is most likely owing to the weakly negative correlation between protein expression levels of HHLA2 in primary tumor tissues and mRNA expression levels of HHLA2 in samples of blood. Generally, the prognostic value of HHLA2 in GC patients needs to be investigated and approved by further studies.

\section{Ig-like Domain-Containing Receptor 2 (ILDR2)}

Ig-like domain-containing receptor 2 (ILDR2) has been newly identified as a B7-like ligand (Figure 1, Table 1) [168]. The encoding gene of ILDR2 is C1orf32, located on Chr1q2325 in humans [169]. Human ILDR2 mRNA can encode type I membrane protein with 639 amino acids. This protein contains a signal peptide, which exists in N-terminus, the intracellular tail (433 amino acid residues), transmembrane domain (20 amino acid residues), and Ig V-set/-type (IgV) domain (167 amino acid residues) [168]. ILDR1 and ILDR3 (lipolysis-stimulated receptor) are known as the two paralogs of ILDR2 [170]. The human ILDR2 represents 94 percent homology with the murine ortholog. The amino acid sequence homology between ILDR2 and other members of the B7 family is approximately 24-36 percent. Protein expression of ILDR2 in humans has been observed on CD56+ lymphocytes, human monocyte-derived from macrophages, and CD16+ monocyte subsets. Expression of ILDR2 mRNA at high levels is detected in the brain and ovaries while it is low in the intestine, heart, and kidney tissues. Moreover, the mouse ILDR2 mRNA expression pattern is similar to the pattern of human ILDR2 mRNA expression [168]. Recombinant ILDR2-Fc fusion protein, without increasing apoptosis of T cells, leads to cell division and inhibits the activation of early TCR signaling. The agonistic activity of ILDR2-Fc on inhibitory receptors suppresses the CD4 and CD8 T lymphocytes activation using monoclonal antibodies against CD3 and CD28 in mice and humans [168]. Despite the inhibitory effect of ILDR2 in T lymphocytes activation, Podojil and colleagues previously showed that ILDR2 has a vital role in the induction of antigen-specific immune tolerance by increased activity of Treg cells and its significant role was revealed in both regulating and modulating immune homeostasis [171]. This immunomodulatory activity related to ILDR2 and its effect on antigen-specific immunological tolerance has been demonstrated in various autoimmune disease models such as mouse models in rheumatoid arthritis (RA), type I 
diabetes, and multiple sclerosis (MS) [168,171]. Recently, the efficacy of the BAY 1905254 as a human/mouse cross-reactive hIgG2 monoclonal antibody against ILDR2 was suggested by Huetter and colleagues. They presented that the antibody targeting ILDR2, BAY 1905254, enhances activation of T lymphocytes and induces responses of antigen-specific $\mathrm{T}$ lymphocytes in vivo via inhibiting the immunosuppressive role of ILDR2. Consequently, BAY 1905254 can induce anti-tumor immune responses in vivo, as monotherapy or in combination with docetaxel and anti-PD-L1 in various syngeneic tumor models [172]. To date, no studies have reported on the role of ILDR2 in pathological states and the clinical significance of ILDR2 expression in GC. Collectively, ILDR2 plays a possible shared role in the progress of both cancer and autoimmune diseases. Therefore, targeting ILDR2 via BAY 1905254 is effective for the immunotherapy of cancer [168].

\section{Treatment of Gastric Cancer Base on B7 Family Inhibition}

Different options are considered for the treatment of GC. Immunotherapy via ICIs is a novel approach for the management of GC [4]. ICIs using monoclonal antibodies have recently gained considerable attention in the treatment of cancer (Figure 2, Table 2). Ipilimumab (fully human IgG1 monoclonal antibody), as a type of anti-cancer drug, targets CTLA-4. In 2011, for the first time, the FDA (U.S. Food and Drug Administration) approved ipilimumab as a second-line setting for the treatment of metastatic melanoma due to its promising efficacy in this cancer [173]. CTLA-4 and PD-1-blocking antibodies were demonstrated to block signaling pathways such as PI3K/AKT, MAPK, and $\beta$-catenin in GC cells. These neutralizing antibodies considerably not only suppressed metastasis and epithelial-mesenchymal transition (EMT) in MGC-803 and MKN-45 cells but also increased the levels of apoptosis. Therefore, combination therapy using CTLA-4 and PD1-blocking antibodies may improve favorable outcomes in GC patients [174]. Another study was conducted by Ralph et al. regarding inhibition of CTLA-4 using tremelimumab as a monoclonal antibody in esophageal adenocarcinoma and metastatic GC patients. Their results show that tremelimumab has an effect in combination with different kinds of immunotherapy [175]. It has been demonstrated that immunotherapy drugs such as nivolumab against PD-1, as monotherapy or in combination with ipilimumab against CTLA4, provide clinical benefit responses (CBR) in phase I/II CheckMate-032 trial. According to this trial, the Overall Response Rate (ORR) in patients who received nivolumab $3 \mathrm{mg} / \mathrm{kg}$ Q2W (N3) was $12 \%$. Likewise, the ORR was $24 \%$ and $8 \%$ in groups of patients who received nivolumab $1 \mathrm{mg} / \mathrm{kg}+$ ipilimumab $3 \mathrm{mg} / \mathrm{kg}$ Q3W (N1 + I3) and nivolumab $3 \mathrm{mg} / \mathrm{kg}+$ ipilimumab $1 \mathrm{mg} / \mathrm{kg}$ Q3W (N3 + I1), respectively [176]. The phase Ib KEYNOTE-012 trial showed that using pembrolizumab can induce anti-tumor immune responses in GC patients with positive PD-L1 expression [177]. Nivolumab, as a checkpoint inhibitor drug that targets PD-1, could improve OS in patients with advanced GC that before received chemotherapy at least two times. The approval is based on the ATTRACTION-02 trial. A phase III trial showed that median survival in the groups that received nivolumab was 5.26 months, while for the groups that received the placebo, median survival was 4.14 months. These results suggest that in prior lines of therapy, nivolumab could be useful as a novel treatment method and care standard in patients with advanced GC that was previously not responsive to chemotherapy [178]. It is noteworthy to report that the KEYNOTE-062 phase III is one of the key trials in the first-line therapy of advanced GC. This trial indicated that 69 percent of GC patients have a PD-L1 combined positive score (CPS) $\geq 10$, and GC patients with CPS $\geq 10$ who received pembrolizumab have prolonged OS in comparison to those patients who received chemotherapy. However, in patients with CPS $\geq 1$, the OS is 11.1 and 10.6 months in groups that received only chemotherapy and pembrolizumab, respectively. This study revealed that in first-line therapy, pembrolizumab compared to chemotherapy has clinically significant effects on the OS of GC patients whose tumors have a CPS score $\geq$ of 10 [179]. It has been demonstrated that in the phase $\mathrm{Ib}$ JAVELIN solid tumor trial, avelumab as first-line maintenance $(1 \mathrm{~L} \mathrm{mn})$ or second-line $(2 \mathrm{~L})$ therapy presented a safety profile with less toxicity in patients with GC. The anti-tumor 
activity of avelumab as an anti-PD-L1 monoclonal antibody was detected in GC patients. It is important to note that more studies are essential for supporting this treatment strategy because of the result of this trial was for a small percentage of GC patients [180]. The phase III KEYNOTE-061 trial was performed in second-line therapy for GC patients with high microsatellite instability (MSI-H) and deficiency of mismatch repair that had disease development due to the use of fluoropyrimidine and platinum as first-line therapy. In this trial, the OS was not reached considerably with pembrolizumab because the OS in patients who were receiving pembrolizumab was 9.1 months while in the chemotherapy group, OS was 8.3 months. However, the use of pembrolizumab over paclitaxel is useful in GC patients with MSI-H [181]. The phase II Clinical KEYNOTE-059 trial approved the use of pembrolizumab in third-line setting for PD-L1 expressing GC who previously received $\geq 2$ lines of therapy such as platinum and fluoropyrimidine. In this trial, ORR was $11.6 \%$ and $15.5 \%$ in all eligible patients and in patients who tested positive for PD-L1, respectively [182]. Another result from the phase III, randomized JAVELIN Gastric 300 trial showed that avelumab as a third-line monotherapy has negative consequences regarding ORR, OS, and PFS in advanced GC patients, while patients who received chemotherapy drugs such as paclitaxel and irinotecan have higher PFS, OS, and ORR. On the other hand, the antitumor activity appeared similar in patients who received chemotherapy or avelumab. However, the safety profile of avelumab is manageable in comparison to chemotherapy [183]. Moreover, the result of a meta-analysis study in 2019 revealed that in GC patients, using anti-PD-1/PD-L1 therapy with a low risk of side effects is more efficient in comparison to anti-CTLA4 therapy. PD-1/ PD-L1 blockade therapy showed better efficacy in GC patients with positive PD-L1 expression, who were Epstein-Barr virus-positive (EBV+), had tumors with high mutation burden, and had high microsatellite instability (MSI-H) [184]. Due to the existence of an association between VISTA and PD-L1 expression in patients with GC, the combination of VISTA and PD-L1 blocking antibodies might be practicable in the treatment of GC patients, considering that it was effective in mouse tumor models [146]. Since VSIG-3 has been discovered as a ligand for the VISTA, it is suggested that targeting the VSIG-3/VISTA pathway via blocking antibodies provides a new approach for the immunotherapy of GC [144]. Targeting B7 family members with blocking antibodies may limit treatment due to side effects in some patients with cancer. Immune-related adverse events (irAEs) such as pneumonitis, endocrinopathies, hepatitis, colitis, and rash are observed. Additionally, it is noteworthy that the occurrence of this side effect is higher in cases where the ipilimumab antibody is used in comparison with cases that are treated with pembrolizumab and nivolumab. Combination therapy of ipilimumab and nivolumab is associated with the prevalence of irAEs. Moreover, skin disorders such as neutrophilic dermatosis are reported as an unfavorable effect of using blocking antibodies in management of cancers. In general, targeting the immune checkpoint proteins using antibodies can be effective in boosting the immune system ability to fight cancer such as GC; thus, the treatment and management of irAEs is necessary so that the use of infliximab or corticosteroids as immunosuppression leads to treatment of irAEs $[185,186]$.

Table 2. Clinical Trials in GC Patients.

\begin{tabular}{|c|c|c|c|c|c|c|c|}
\hline Target & Antibody & Combination Treatment & Identifier & Phase & Cancer & Status & Reference \\
\hline Anti-PD-L1 & Avelumab & $\begin{array}{l}\text { Irinotecan } \\
\text { Paclitaxel }\end{array}$ & NCT02625623 & III & GC & Completed & [187] \\
\hline Anti-PD-L1 & Avelumab & $\begin{array}{c}\text { Oxaliplatin } \\
\text { 5-FU } \\
\text { Leucovorin } \\
\text { Capecitabine }\end{array}$ & NCT02625610 & III & GC & $\begin{array}{l}\text { Active, not } \\
\text { recruiting }\end{array}$ & [188] \\
\hline $\begin{array}{c}\text { Anti-PD-1 } \\
\text { Anti-CTLA-4 }\end{array}$ & $\begin{array}{l}\text { Nivolumab } \\
\text { Ipilimumab }\end{array}$ & OTSGC-A24 & NCT03784040 & I & GC & Recruiting & [189] \\
\hline Anti-PD-L1 & Nivolumab & Radiotherapy & NCT03453164 & $\mathrm{I} / \mathrm{II}$ & GC & $\begin{array}{c}\text { Active, } \\
\text { recruiting }\end{array}$ & [190] \\
\hline $\begin{array}{c}\text { Anti-PD-1 } \\
\text { Anti-CTLA-4 }\end{array}$ & $\begin{array}{l}\text { Nivolumab } \\
\text { Ipilimumab }\end{array}$ & - & NCT03342417 & II & $\begin{array}{l}\text { GC, Ovarian } \\
\text { cancer, Breast } \\
\text { Cancer }\end{array}$ & $\begin{array}{l}\text { Terminated } \\
\text { (Slow patient } \\
\text { accrual) }\end{array}$ & [191] \\
\hline
\end{tabular}


Table 2. Cont.

\begin{tabular}{|c|c|c|c|c|c|c|c|}
\hline Target & Antibody & Combination Treatment & Identifier & Phase & Cancer & Status & Reference \\
\hline Anti-PD-L1 & Nivolumab & $\begin{array}{c}\text { Tegafur/gimeracil/oteracil } \\
\text { Oxaliplatin } \\
\text { Capecitabine } \\
\text { Placebo }\end{array}$ & NCT03006705 & III & GC & Recruiting & [192] \\
\hline $\begin{array}{c}\text { Anti-PD-1 } \\
\text { Anti-CTLA-4 }\end{array}$ & $\begin{array}{l}\text { Nivolumab } \\
\text { Ipilimumab }\end{array}$ & chemotherapy & NCT03443856 & II & $\begin{array}{l}\text { GC, gastroe- } \\
\text { sophageal } \\
\text { junction adeno- } \\
\text { carcinoma }\end{array}$ & Recruiting & [193] \\
\hline Anti-PD-L1 & Pembrolizumab & $\begin{array}{l}\text { Cisplatin } \\
\text { 5-FU } \\
\text { Capecitabine }\end{array}$ & NCT02335411 & II & $\begin{array}{l}\text { GC, gastroe- } \\
\text { sophageal } \\
\text { junction adeno- } \\
\text { carcinoma }\end{array}$ & $\begin{array}{l}\text { Active, not } \\
\text { recruiting }\end{array}$ & [194] \\
\hline Anti-PD-L1 & Pembrolizumab & $\begin{array}{l}\text { Cisplatin } \\
\text { 5-FU } \\
\text { Capecitabine } \\
\text { Placebo }\end{array}$ & NCT02494583 & III & GC & $\begin{array}{l}\text { Active, not } \\
\text { recruiting }\end{array}$ & [195] \\
\hline Anti-PD-L1 & $\begin{array}{l}\text { Pembrolizumab } \\
\text { Nivolumab }\end{array}$ & DSP-7888 Dosing Emulsion & NCT03311334 & $\mathrm{I} / \mathrm{II}$ & $\begin{array}{l}\text { Melanoma, GC, } \\
\text { Colorectal } \\
\text { Cancer, etc. } \\
\text { GC, Colorectal }\end{array}$ & Recruiting & [196] \\
\hline Anti-PD-L1 & $\begin{array}{c}\text { Pembrolizumab } \\
\text { Nivolumab }\end{array}$ & $\begin{array}{c}\text { FT500 } \\
\text { Atezolizumab } \\
\text { Cyclophosphamide } \\
\text { Fludarabine } \\
\text { IL-2 }\end{array}$ & NCT03841110 & I & $\begin{array}{c}\text { Cancer, } \\
\text { Hepatocellular } \\
\text { carcinoma, } \\
\text { Small Cell } \\
\text { Lung Cancer, } \\
\text { Renal Cell } \\
\text { Carcinoma, etc. }\end{array}$ & Recruiting & [197] \\
\hline
\end{tabular}

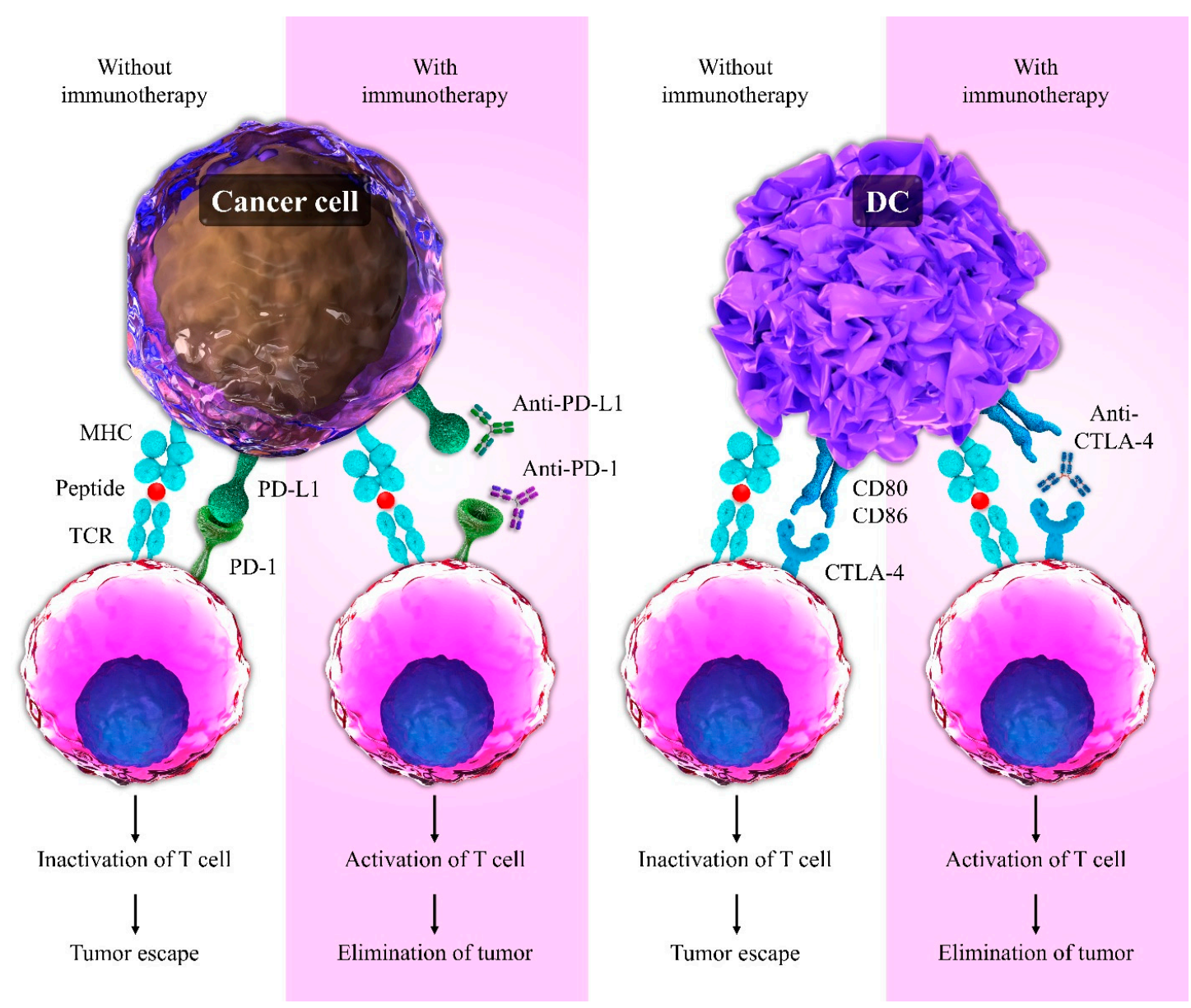

Figure 2. Comparison of the use of immunotherapy and non-use of this method in T cell response. Interaction of PD-L1 with PD-1 and CD80/CD86 with CTLA-4 leads to the inactivation of T lymphocytes, and tumors can escape from the immune system. In contrast, immunotherapy using CTLA-4 and PD-1-blocking antibodies causes the elimination of tumors by promoting increased $\mathrm{T}$ cell activation. 


\section{Conclusions}

GC is one of the most prevalent kinds of cancer and heterogeneous malignancy. A combination of particular genetic alterations, as well as environmental risk factors, account for GC. Delays in the diagnosis and the consequently high incidence/mortality of this cancer are significant reasons GC is such a challenging malignancy. Surgery, chemotherapy, and sometimes radiation therapy is most often used to treat GC patients. However, due to the low survival rates of these patients after the use of common treatments, it is demonstrated that immunotherapy has a prominent function in cancer therapy. One of the methods related to immunotherapy is using ICIs targeting the inhibitory B7 family members, which delivered promising results for patients with GC. Several members of the B7 family have been recognized as having considerable functions in regulating and directing $\mathrm{T}$ cell fate through their interactions with corresponding receptors. The expression of members of this family has clinical significance in GC. Evaluation of the B7 family members' expression can be a valuable prognostic factor for early diagnosis and treatment in GC patients. For the management of GC, several clinical trials of different phases have been conducted to study the effect of using blocking antibodies against members of the B7 family. Mainly, targeting the PD-1/PD-L1 axis by neutralizing antibodies such as pembrolizumab and nivolumab has been appearing as a new approach in the management of advanced GC. Despite the fact that ICIs in different clinical trials are considered as a novel method in the advanced GC treatment, emerging new approaches are required to confirm the most efficient ICIs in GC, either as monotherapy or through combining ICIs with vaccines, radiotherapy, and agents with immunomodulatory characteristics [198]. Moreover, combination therapy can overcome the challenges of shorter-lasting cytotoxic chemotherapy responses and the delayed response of immune checkpoint inhibitors. Consequently, ICIs might pave the acceptable standard way of care for the treatment of GC patients.

Author Contributions: N.B. provided the initial version of the paper. Z.A., N.H., A.B., A.D., M.A.N. and O.B. helped in data categorization and critically reviewed the manuscript. R.B. revised the paper and left some comments. B.B. and N.S., the corresponding authors of the manuscript, provided financial support for the work, supervised the project, and revised the main text of the manuscript. All authors have read and agreed to the published version of the manuscript.

Funding: This research received no external funding.

Institutional Review Board Statement: Not applicable.

Informed Consent Statement: Not applicable.

Data Availability Statement: Not available.

Acknowledgments: This study was supported by the Immunology Research Center, Tabriz University of Medical Sciences, Tabriz, Iran.

Conflicts of Interest: The authors declare that they have no conflict of interest.

\section{References}

1. Ferlay, J.; Colombet, M.; Soerjomataram, I.; Mathers, C.; Parkin, D.M.; Piñeros, M.; Znaor, A.; Bray, F. Estimating the global cancer incidence and mortality in 2018: GLOBOCAN sources and methods. Int. J. Cancer 2019, 144, 1941-1953. [CrossRef]

2. Hamashima, C.; Systematic Review Group; Systematic Review Group and Guideline Development Group for Gastric Cancer Screening Guidelines. Update version of the Japanese Guidelines for Gastric Cancer Screening. Jpn. J. Clin. Oncol. 2018, 48, 673-683. [CrossRef]

3. Alsina, M.; Moehler, M.; Hierro, C.; Guardeño, R.; Tabernero, J. Immunotherapy for gastric cancer: A focus on immune checkpoints. Target. Oncol. 2016, 11, 469-477. [CrossRef]

4. Abdul-Latif, M.; Townsend, K.; Dearman, C.; Shiu, K.K.; Khan, K. Immunotherapy in gastrointestinal cancer: The current scenario and future perspectives. Cancer Treat. Rev. 2020, 88, 102030. [CrossRef]

5. Su, M.; Lin, Y.; Cui, C.; Tian, X.; Lai, L. ERMAP is a B7 family-related molecule that negatively regulates T cell and macrophage responses. Cell. Mol. Immunol. 2020, 18, 1920-1933. [CrossRef] [PubMed]

6. Ni, L.; Dong, C. New B7 family checkpoints in human cancers. Mol. Cancer Ther. 2017, 16, 1203-1211. [CrossRef] [PubMed] 
7. Liu, W.; Zang, X. Structures of Immune Checkpoints: An Overview on the CD28-B7 Family. In Structural Immunology; Springer: Berlin/Heidelberg, Germany, 2019; Volume 1172, pp. 63-78.

8. Ye, Q.; Liu, J.; Xie, K. B7 Family proteins in cancer progression: Immunological and non-immunological functions. J. Cancer Treat. Diagn. 2019, 3, 1-6. [CrossRef]

9. Kong, X. Discovery of new immune checkpoints: Family grows up. In Regulation of Cancer Immune Checkpoints; Springer: Berlin/Heidelberg, Germany, 2020; Volume 1248, pp. 61-82.

10. Chapoval, A.; Chapoval, S.; Shcherbakova, N.; Shcherbakov, D. Immune checkpoints of the B7 family. Part 2. Representatives of the B7 family B7-H3, B7-H4, B7-H5, B7-H6, B7-H7, and ILDR2 and their receptors. Russ. J. Bioorg. Chem. 2019, 45, 321-334. [CrossRef]

11. Barrueto, L.; Caminero, F.; Cash, L.; Makris, C.; Lamichhane, P.; Deshmukh, R.R. Resistance to checkpoint inhibition in cancer immunotherapy. Transl. Oncol. 2020, 13, 100738. [CrossRef]

12. Sadreddini, S.; Baradaran, B.; Aghebati-Maleki, A.; Sadreddini, S.; Shanehbandi, D.; Fotouhi, A.; Aghebati-Maleki, L. Immune checkpoint blockade opens a new way to cancer immunotherapy. J. Cell. Physiol. 2019, 234, 8541-8549. [CrossRef] [PubMed]

13. Zhu, H.F.; Li, Y. Small-molecule targets in tumor immunotherapy. Nat. Prod. Bioprospect. 2018, 8, 297-301. [CrossRef]

14. Bhatia, S.; Edidin, M.; Almo, S.C.; Nathenson, S.G. Different cell surface oligomeric states of B7-1 and B7-2: Implications for signaling. Proc. Natl. Acad. Sci. USA 2005, 102, 15569-15574. [CrossRef]

15. Fleischer, J.; Soeth, E.; Reiling, N.; Grage-Griebenow, E.; Flad, H.D.; Ernst, M. Differential expression and function of CD80 (B7-1) and CD86 (B7-2) on human peripheral blood monocytes. Immunology 1996, 89, 592-598. [CrossRef] [PubMed]

16. Esensten, J.H.; Helou, Y.A.; Chopra, G.; Weiss, A.; Bluestone, J.A. CD28 Costimulation: From mechanism to therapy. Immunity 2016, 44, 973-988. [CrossRef] [PubMed]

17. Elloso, M.M.; Scott, P. Expression and contribution of B7-1 (CD80) and B7-2 (CD86) in the early immune response to Leishmania major infection. J. Immunol. 1999, 162, 6708-6715. [PubMed]

18. Brunet, J.F.; Denizot, F.; Luciani, M.F.; Roux-Dosseto, M.; Suzan, M.; Mattei, M.G.; Golstein, P. A new member of the immunoglobulin superfamily-CTLA-4. Nature 1987, 328, 267-270. [CrossRef]

19. Dariavach, P.; Mattéi, M.G.; Golstein, P.; Lefranc, M.P. Human Ig superfamily CTLA-4 gene: Chromosomal localization and identity of protein sequence between murine and human CTLA-4 cytoplasmic domains. Eur. J. Immunol. 1988, 18, 1901-1905. [CrossRef] [PubMed]

20. Howard, T.A.; Rochelle, J.M.; Seldin, M.F. Cd28 and Ctla-4, two related members of the Ig supergene family, are tightly linked on proximal mouse chromosome 1. Immunogenetics 1991, 33, 74-76. [CrossRef] [PubMed]

21. Zhao, Y.; Yang, W.; Huang, Y.; Cui, R.; Li, X.; Li, B. Evolving roles for targeting CTLA-4 in cancer immunotherapy. Cellular physiology and biochemistry. Int. J. Exp. Cell. Physiol. Biochem. Pharmacol. 2018, 47, 721-734. [CrossRef] [PubMed]

22. Laurent, S.; Carrega, P.; Saverino, D.; Piccioli, P.; Camoriano, M.; Morabito, A.; Dozin, B.; Fontana, V.; Simone, R.; Mortara, L.; et al. CTLA-4 is expressed by human monocyte-derived dendritic cells and regulates their functions. Hum. Immunol. 2010, 71, 934-941. [CrossRef] [PubMed]

23. Rozanski, C.H.; Arens, R.; Carlson, L.M.; Nair, J.; Boise, L.H.; Chanan-Khan, A.A.; Schoenberger, S.P.; Lee, K.P. Sustained antibody responses depend on CD28 function in bone marrow-resident plasma cells. J. Exp. Med. 2011, 208, 1435-1446. [CrossRef] [PubMed]

24. Dustin, M.L. The immunological synapse. Cancer Immunol. Res. 2014, 2, 1023-1033. [CrossRef] [PubMed]

25. Buchbinder, E.I.; Desai, A. CTLA-4 and PD-1 Pathways: Similarities, differences, and implications of their inhibition. Am. J. Clin. Oncol. 2016, 39, 98-106. [CrossRef] [PubMed]

26. Engelhardt, J.J.; Sullivan, T.J.; Allison, J.P. CTLA-4 overexpression inhibits T cell responses through a CD28-B7-dependent mechanism. J. Immunol. 2006, 177, 1052-1061. [CrossRef] [PubMed]

27. Krummel, M.F.; Allison, J.P. CD28 and CTLA-4 have opposing effects on the response of T cells to stimulation. J. Exp. Med. 1995 182, 459-465. [CrossRef] [PubMed]

28. Yokosuka, T.; Takamatsu, M.; Kobayashi-Imanishi, W.; Hashimoto-Tane, A.; Azuma, M.; Saito, T. Programmed cell death 1 forms negative costimulatory microclusters that directly inhibit T cell receptor signaling by recruiting phosphatase SHP2. J. Exp. Med. 2012, 209, 1201-1217. [CrossRef]

29. Cetin, B.; Gumusay, O.; Cengiz, M.; Ozet, A. Advances of molecular targeted therapy in gastric cancer. J. Gastrointest. Cancer 2016, 47, 125-134. [CrossRef] [PubMed]

30. Lens, M.; Ferrucci, P.F.; Testori, A. Anti-CTLA4 monoclonal antibody Ipilimumab in the treatment of metastatic melanoma: Recent findings. Recent Pat. Anti-Cancer Drug Discov. 2008, 3, 105-113. [CrossRef]

31. Sakate, Y.; Yashiro, M.; Tanaka, H.; Sunami, T.; Kosaka, K.; Hirakawa, K. Usefulness of inhibiting the lymph node metastasis in human gastric carcinoma by B7-1 gene transfection1. J. Surg. Res. 2004, 122, 89-95. [CrossRef]

32. Sakate, Y.; Yashiro, M.; Tanaka, H.; Kosaka, K.; Ohira, M.; Hirakawa, K. Suppression of peritoneal metastasis in human gastric carcinoma by enhanced immunogenicity of B7-1 transfection. Oncol. Rep. 2004, 12, 53-57. [CrossRef]

33. Chen, L.; Zhu, D.; Feng, J.; Zhou, Y.; Wang, Q.; Feng, H.; Zhang, J.; Jiang, J. Overexpression of HHLA2 in human clear cell renal cell carcinoma is significantly associated with poor survival of the patients. Cancer Cell Int. 2019, 19, 101. [CrossRef]

34. Yang, X.; Lv, T.; Qiang, J.; Li, X.; Zheng, C.; Ding, J.; Lim, Z.; Pang, L.; Du, W.; Zhu, P.; et al. Expression and significance of CD28, CTLA-4, CD80 and CD86 in gastric cancer. Biomed. Res. 2017, 28, 10159-10164. 
35. Yao, S.; Zhu, Y.; Zhu, G.; Augustine, M.; Zheng, L.; Goode, D.J.; Broadwater, M.; Ruff, W.; Flies, S.; Xu, H.; et al. B7-h2 is a costimulatory ligand for CD28 in human. Immunity 2011, 34, 729-740. [CrossRef] [PubMed]

36. Chen, L.; Flies, D. Molecular mechanisms of T cell co-stimulation and co-inhibition. Nat. Rev. Immunol. 2013, 13, 542. [CrossRef]

37. Amatore, F.; Gorvel, L.; Olive, D. Role of Inducible Co-Stimulator (ICOS) in cancer immunotherapy. Expert Opin. Biol. Ther. 2020, 20, 141-150. [CrossRef] [PubMed]

38. Wikenheiser, D.J.; Stumhofer, J.S. ICOS co-stimulation: Friend or foe? Front. Immunol. 2016, 7, 304. [CrossRef]

39. Khayyamian, S.; Hutloff, A.; Büchner, K.; Gräfe, M.; Henn, V.; Kroczek, R.A.; Mages, H.W. ICOS-ligand, expressed on human endothelial cells, costimulates Th1 and Th2 cytokine secretion by memory CD4+ T cells. Proc. Natl. Acad. Sci. USA 2002, 99, 6198-6203. [CrossRef] [PubMed]

40. Tamura, H.; Dan, K.; Tamada, K.; Nakamura, K.; Shioi, Y.; Hyodo, H.; Wang, S.D.; Dong, H.; Chen, L.; Ogata, K. Expression of functional B7-H2 and B7.2 costimulatory molecules and their prognostic implications in de novo acute myeloid leukemia. Clin. Cancer Res. Off. J. Am. Assoc. Cancer Res. 2005, 11, 5708-5717. [CrossRef]

41. Klingenberg, R.; Autschbach, F.; Gleissner, C.; Giese, T.; Wambsganss, N.; Sommer, N.; Richter, G.; Katus, H.A.; Dengler, T.J. Endothelial inducible costimulator ligand expression is increased during human cardiac allograft rejection and regulates endothelial cell-dependent allo-activation of CD8+ T cells in vitro. Eur. J. Immunol. 2005, 35, 1712-1721. [CrossRef]

42. Schenk, A.D.; Gorbacheva, V.; Rabant, M.; Fairchild, R.L.; Valujskikh, A. Effector functions of donor-reactive CD8 memory T cells are dependent on ICOS induced during division in cardiac grafts. Am. J. Transplant. Off. J. Am. Soc. Transplant. Am. Soc. Transpl. Surg. 2009, 9, 64-73. [CrossRef] [PubMed]

43. Linterman, M.A.; Rigby, R.J.; Wong, R.; Silva, D.; Withers, D.; Anderson, G.; Verma, N.K.; Brink, R.; Hutloff, A.; Goodnow, C.C.; et al. Roquin differentiates the specialized functions of duplicated $\mathrm{T}$ cell costimulatory receptor genes CD28 and ICOS. Immunity 2009, 30, 228-241. [CrossRef]

44. Choi, Y.S.; Kageyama, R.; Eto, D.; Escobar, T.C.; Johnston, R.J.; Monticelli, L.; Lao, C.; Crotty, S. ICOS receptor instructs T follicular helper cell versus effector cell differentiation via induction of the transcriptional repressor Bcl6. Immunity 2011, 34, 932-946. [CrossRef]

45. Scott, G.B.; Carter, C.; Parrish, C.; Wood, P.M.; Cook, G. Downregulation of myeloma-induced ICOS-L and regulatory T cell generation by lenalidomide and dexamethasone therapy. Cell. Immunol. 2015, 297, 1-9. [CrossRef]

46. Wang, S.; Zhu, G.; Chapoval, A.I.; Dong, H.; Tamada, K.; Ni, J.; Chen, L. Costimulation of T cells by B7-H2, a B7-like molecule that binds ICOS. Blood 2000, 96, 2808-2813. [CrossRef]

47. Park, H.; Li, Z.; Yang, X.O.; Chang, S.H.; Nurieva, R.; Wang, Y.H.; Wang, Y.; Hood, L.; Zhu, Z.; Tian, Q.; et al. A distinct lineage of CD4 T cells regulates tissue inflammation by producing interleukin 17. Nat. Immunol. 2005, 6, 1133-1141. [CrossRef]

48. Dong, C.; Juedes, A.E.; Temann, U.A.; Shresta, S.; Allison, J.P.; Ruddle, N.H.; Flavell, R.A. ICOS co-stimulatory receptor is essential for T-cell activation and function. Nature 2001, 409, 97-101. [CrossRef] [PubMed]

49. Wallin, J.J.; Liang, L.; Bakardjiev, A.; Sha, W.C. Enhancement of CD8+ T cell responses by ICOS/B7h costimulation. J. Immunol. 2001, 167, 132-139. [CrossRef] [PubMed]

50. Burmeister, Y.; Lischke, T.; Dahler, A.C.; Mages, H.W.; Lam, K.P.; Coyle, A.J.; Kroczek, R.A.; Hutloff, A. ICOS controls the pool size of effector-memory and regulatory T cells. J. Immunol. 2008, 180, 774-782. [CrossRef] [PubMed]

51. Solinas, C.; Gu-Trantien, C.; Willard-Gallo, K. The rationale behind targeting the ICOS-ICOS ligand costimulatory pathway in cancer immunotherapy. ESMO Open 2020, 5, e000544. [CrossRef]

52. Nagase, H.; Takeoka, T.; Urakawa, S.; Morimoto-Okazawa, A.; Kawashima, A.; Iwahori, K.; Takiguchi, S.; Nishikawa, H.; Sato, E.; Sakaguchi, S.; et al. ICOS(+) Foxp3(+) TILs in gastric cancer are prognostic markers and effector regulatory T cells associated with Helicobacter pylori. Int. J. Cancer 2017, 140, 686-695. [CrossRef]

53. Huang, X.-M.; Liu, X.-S.; Lin, X.-K.; Yu, H.; Sun, J.-Y.; Liu, X.-K.; Chen, C.; Jin, H.-L.; Zhang, G.-E.; Shi, X.-X.; et al. Role of plasmacytoid dendritic cells and inducible costimulator-positive regulatory $\mathrm{T}$ cells in the immunosuppression microenvironment of gastric cancer. Cancer Sci. 2014, 105, 150-158. [CrossRef] [PubMed]

54. Tsukamoto, Y.; Nakada, C.; Noguchi, T.; Tanigawa, M.; Nguyen, L.T.; Uchida, T.; Hijiya, N.; Matsuura, K.; Fujioka, T.; Seto, M.; et al. MicroRNA-375 is downregulated in gastric carcinomas and regulates cell survival by targeting PDK1 and 14-3-3zeta. Cancer Res. 2010, 70, 2339-2349. [CrossRef] [PubMed]

55. Mishra, P.J.; Song, B.; Mishra, P.J.; Wang, Y.; Humeniuk, R.; Banerjee, D.; Merlino, G.; Ju, J.; Bertino, J.R. MiR-24 tumor suppressor activity is regulated independent of p53 and through a target site polymorphism. PLoS ONE 2009, 4, e8445. [CrossRef]

56. Yang, P.; Tang, R.; Zhu, J.; Zou, L.; Wu, R.; Zhou, H.; Mao, Y.; Li, R.; Hua, D.; Wang, W.; et al. A functional variant at miR-24 binding site in B7-H2 alters susceptibility to gastric cancer in a Chinese Han population. Mol. Immunol. 2013, 56, 98-103. [CrossRef]

57. Sharpe, A.H.; Wherry, E.J.; Ahmed, R.; Freeman, G.J. The function of programmed cell death 1 and its ligands in regulating autoimmunity and infection. Nat. Immunol. 2007, 8, 239-245. [CrossRef]

58. Riella, L.V.; Watanabe, T.; Sage, P.T.; Yang, J.; Yeung, M.; Azzi, J.; Vanguri, V.; Chandraker, A.; Sharpe, A.H.; Sayegh, M.H.; et al. Essential role of PDL1 expression on nonhematopoietic donor cells in acquired tolerance to vascularized cardiac allografts. Am. J. Transplant. Off. J. Am. Soc. Transplant. Am. Soc. Transpl. Surg. 2011, 11, 832-840. [CrossRef]

59. Keir, M.E.; Butte, M.J.; Freeman, G.J.; Sharpe, A.H. PD-1 and its ligands in tolerance and immunity. Annu. Rev. Immunol. 2008, 26, 677-704. [CrossRef] 
60. Okazaki, T.; Honjo, T. PD-1 and PD-1 ligands: From discovery to clinical application. Int. Immunol. 2007, 19, 813-824. [CrossRef]

61. Greaves, P.; Gribben, J.G. The role of B7 family molecules in hematologic malignancy. Blood 2013, 121, 734-744. [CrossRef]

62. Neel, B.G.; Gu, H.; Pao, L. The 'Shp'ing news: SH2 domain-containing tyrosine phosphatases in cell signaling. Trends Biochem. Sci. 2003, 28, 284-293. [CrossRef]

63. Viricel, C.; Ahmed, M.; Barakat, K. Human PD-1 binds differently to its human ligands: A comprehensive modeling study. J. Mol. Graph. Model. 2015, 57, 131-142. [CrossRef] [PubMed]

64. Freeman, G.J.; Long, A.J.; Iwai, Y.; Bourque, K.; Chernova, T.; Nishimura, H.; Fitz, L.J.; Malenkovich, N.; Okazaki, T.; Byrne, M.C.; et al. Engagement of the PD-1 immunoinhibitory receptor by a novel B7 family member leads to negative regulation of lymphocyte activation. J. Exp. Med. 2000, 192, 1027-1034. [CrossRef]

65. Butte, M.J.; Keir, M.E.; Phamduy, T.B.; Sharpe, A.H.; Freeman, G.J. Programmed death-1 ligand 1 interacts specifically with the B7-1 costimulatory molecule to inhibit T cell responses. Immunity 2007, 27, 111-122. [CrossRef]

66. Han, Y.; Liu, D.; Li, L. PD-1/PD-L1 pathway: Current researches in cancer. Am. J. Cancer Res. 2020, 10, 727-742. [PubMed]

67. Taube, J.M.; Anders, R.A.; Young, G.D.; Xu, H.; Sharma, R.; McMiller, T.L.; Chen, S.; Klein, A.P.; Pardoll, D.M.; Topalian, S.L.; et al. Colocalization of inflammatory response with B7-h1 expression in human melanocytic lesions supports an adaptive resistance mechanism of immune escape. Sci. Transl. Med. 2012, 4, 127ra137. [CrossRef] [PubMed]

68. Crane, C.A.; Panner, A.; Murray, J.C.; Wilson, S.P.; Xu, H.; Chen, L.; Simko, J.P.; Waldman, F.M.; Pieper, R.O.; Parsa, A.T. PI(3) kinase is associated with a mechanism of immunoresistance in breast and prostate cancer. Oncogene 2009, 28, 306-312. [CrossRef] [PubMed]

69. Wu, X.; Li, Y.; Liu, X.; Cao, S.; Harrington, S.M.; Chen, C.; Mansfiled, A.S.; Dronca, R.S.; Park, S.S.; Yan, Y.; et al. B7-H1(PD-L1) confers chemoresistance through ERK and p38 MAPK pathway in tumor cells. bioRxiv 2018, 308601. [CrossRef]

70. Liu, X.; Yang, Z.; Latchoumanin, O.; Qiao, L. Antagonizing programmed death-1 and programmed death ligand-1 as a therapeutic approach for gastric cancer. Ther. Adv. Gastroenterol. 2016, 9, 853-860. [CrossRef]

71. Zheng, X.; Dong, L.; Wang, K.; Zou, H.; Zhao, S.; Wang, Y.; Wang, G. MiR-21 participates in the PD-1/PD-L1 pathway-mediated imbalance of Th17/Treg cells in patients after gastric cancer resection. Ann. Surg. Oncol. 2019, 26, 884-893. [CrossRef]

72. Zhang, L.; Qiu, M.; Jin, Y.; Ji, J.; Li, B.; Wang, X.; Yan, S.; Xu, R.; Yang, D. Programmed cell death ligand 1 (PD-L1) expression on gastric cancer and its relationship with clinicopathologic factors. Int. J. Clin. Exp. Pathol. 2015, 8, 11084-11091.

73. Chakrabarti, J.; Holokai, L.; Syu, L.; Steele, N.G.; Chang, J.; Wang, J.; Ahmed, S.; Dlugosz, A.; Zavros, Y. Hedgehog signaling induces PD-L1 expression and tumor cell proliferation in gastric cancer. Oncotarget 2018, 9, 37439-37457. [CrossRef]

74. Geng, Y.; Wang, H.; Lu, C.; Li, Q.; Xu, B.; Jiang, J.; Wu, C. Expression of costimulatory molecules B7-H1, B7-H4 and Foxp3+ Tregs in gastric cancer and its clinical significance. Int. J. Clin. Oncol. 2015, 20, 273-281. [CrossRef]

75. Wang, W.; Sun, J.; Li, F.; Li, R.; Gu, Y.; Liu, C.; Yang, P.; Zhu, M.; Chen, L.; Tian, W.; et al. A frequent somatic mutation in CD274 3'-UTR leads to protein over-expression in gastric cancer by disrupting miR-570 binding. Hum. Mutat. 2012, 33, 480-484. [CrossRef]

76. Imai, Y.; Chiba, T.; Kondo, T.; Kanzaki, H.; Kanayama, K.; Ao, J.; Kojima, R.; Kusakabe, Y.; Nakamura, M.; Saito, T.; et al. Interferon- $\gamma$ induced PD-L1 expression and soluble PD-L1 production in gastric cancer. Oncol. Lett. 2020, 20, $2161-2168$. [CrossRef]

77. Oki, E.; Okano, S.; Saeki, H.; Umemoto, Y.; Teraishi, K.; Nakaji, Y.; Ando, K.; Zaitsu, Y.; Yamashita, N.; Sugiyama, M.; et al. Protein expression of programmed death 1 ligand 1 and HER2 in gastric carcinoma. Oncology 2017, 93, 387-394. [CrossRef]

78. Menyhárt, O.; Pongor, L.S.; Győrffy, B. Mutations defining patient cohorts with elevated PD-L1 expression in gastric cancer. Front. Pharm. 2019, 9, 1522. [CrossRef] [PubMed]

79. Deng, R.; Zhang, P.; Liu, W.; Zeng, X.; Ma, X.; Shi, L.; Wang, T.; Yin, Y.; Chang, W.; Zhang, P.; et al. HDAC is indispensable for IFN- $\gamma$-induced B7-H1 expression in gastric cancer. Clin. Epigenet. 2018, 10, 153. [CrossRef] [PubMed]

80. Dong, M.; Wang, H.-Y.; Zhao, X.-X.; Chen, J.-N.; Zhang, Y.-W.; Huang, Y.; Xue, L.; Li, H.-G.; Du, H.; Wu, X.-Y.; et al. Expression and prognostic roles of PIK3CA, JAK2, PD-L1, and PD-L2 in Epstein-Barr virus-associated gastric carcinoma. Hum. Pathol. 2016, 53, 25-34. [CrossRef] [PubMed]

81. Nakayama, Y.; Mimura, K.; Kua, L.-F.; Okayama, H.; Min, A.K.T.; Saito, K.; Hanayama, H.; Watanabe, Y.; Saito, M.; Momma, T.; et al. Immune suppression caused by PD-L2 expression on tumor cells in gastric cancer. Gastric Cancer 2020, 23, 961-973. [CrossRef]

82. Saito, H.; Kuroda, H.; Matsunaga, T.; Osaki, T.; Ikeguchi, M. Increased PD-1 expression on CD4+ and CD8+ T cells is involved in immune evasion in gastric cancer. J. Surg. Oncol. 2013, 107, 517-522. [CrossRef] [PubMed]

83. Chang, H.; Jung, W.Y.; Kang, Y.; Lee, H.; Kim, A.; Kim, H.K.; Shin, B.K.; Kim, B.-H. Programmed death-ligand 1 expression in gastric adenocarcinoma is a poor prognostic factor in a high CD8+ tumor infiltrating lymphocytes group. Oncotarget 2016, 7 , 80426-80434. [CrossRef]

84. Thompson, E.D.; Zahurak, M.; Murphy, A.; Cornish, T.; Cuka, N.; Abdelfatah, E.; Yang, S.; Duncan, M.; Ahuja, N.; Taube, J.M.; et al. Patterns of PD-L1 expression and CD8 T cell infiltration in gastric adenocarcinomas and associated immune stroma. Gut 2017, 66, 794-801. [CrossRef]

85. Sun, M.; Richards, S.; Prasad, D.V.; Mai, X.M.; Rudensky, A.; Dong, C. Characterization of mouse and human B7-H3 genes. J. Immunol. 2002, 168, 6294-6297. [CrossRef] [PubMed] 
86. Chapoval, A.I.; Ni, J.; Lau, J.S.; Wilcox, R.A.; Flies, D.B.; Liu, D.; Dong, H.; Sica, G.L.; Zhu, G.; Tamada, K.; et al. B7-H3: A costimulatory molecule for T cell activation and IFN-gamma production. Nat. Immunol. 2001, 2, 269-274. [CrossRef] [PubMed]

87. Mahnke, K.; Ring, S.; Johnson, T.S.; Schallenberg, S.; Schönfeld, K.; Storn, V.; Bedke, T.; Enk, A.H. Induction of immunosuppressive functions of dendritic cells in vivo by CD4+CD25+ regulatory T cells: Role of B7-H3 expression and antigen presentation. Eur. J. Immunol. 2007, 37, 2117-2126. [CrossRef] [PubMed]

88. Ni, L.; Dong, C. New checkpoints in cancer immunotherapy. Immunol. Rev. 2017, 276, 52-65. [CrossRef]

89. Xu, H.; Cheung, I.Y.; Guo, H.-F.; Cheung, N.-K.V. MicroRNA miR-29 modulates expression of immunoinhibitory molecule B7-H3: Potential implications for immune based therapy of human solid tumors. Cancer Res. 2009, 69, 6275-6281. [CrossRef]

90. Suh, W.K.; Gajewska, B.U.; Okada, H.; Gronski, M.A.; Bertram, E.M.; Dawicki, W.; Duncan, G.S.; Bukczynski, J.; Plyte, S.; Elia, A.; et al. The B7 family member B7-H3 preferentially down-regulates T helper type 1-mediated immune responses. Nat. Immunol. 2003, 4, 899-906. [CrossRef]

91. Prasad, D.; Nguyen, T.; Li, Z.; Yang, Y.; Duong, J.; Wang, Y.; Dong, C. Murine B7-H3 is a negative regulator of T cells. J. Immunol. 2004, 173, 2500-2506. [CrossRef]

92. Hofmeyer, K.A.; Ray, A.; Zang, X. The contrasting role of B7-H3. Proc. Natl. Acad. Sci. USA 2008, 105, 10277-10278. [CrossRef] [PubMed]

93. Veenstra, R.G.; Flynn, R.; Kreymborg, K.; McDonald-Hyman, C.; Saha, A.; Taylor, P.A.; Osborn, M.J.; Panoskaltsis-Mortari, A.; Schmitt-Graeff, A.; Lieberknecht, E.; et al. B7-H3 expression in donor T cells and host cells negatively regulates acute graft-versus-host disease lethality. Blood 2015, 125, 3335-3346. [CrossRef] [PubMed]

94. Suh, W.K.; Wang, S.X.; Jheon, A.H.; Moreno, L.; Yoshinaga, S.K.; Ganss, B.; Sodek, J.; Grynpas, M.D.; Mak, T.W. The immune regulatory protein B7-H3 promotes osteoblast differentiation and bone mineralization. Proc. Natl. Acad. Sci. USA 2004, 101, 12969-12973. [CrossRef]

95. Castriconi, R.; Dondero, A.; Augugliaro, R.; Cantoni, C.; Carnemolla, B.; Sementa, A.R.; Negri, F.; Conte, R.; Corrias, M.V.; Moretta, L.; et al. Identification of 4Ig-B7-H3 as a neuroblastoma-associated molecule that exerts a protective role from an NK cell-mediated lysis. Proc. Natl. Acad. Sci. USA 2004, 101, 12640-12645. [CrossRef]

96. Hashiguchi, M.; Kobori, H.; Ritprajak, P.; Kamimura, Y.; Kozono, H.; Azuma, M. From the Cover: Triggering receptor expressed on myeloid cell-like transcript 2 (TLT-2) is a counter-receptor for B7-H3 and enhances T cell responses. Proc. Natl. Acad. Sci. USA 2008, 105, 10495-10500. [CrossRef]

97. Leitner, J.; Klauser, C.; Pickl, W.F.; Stöckl, J.; Majdic, O.; Bardet, A.F.; Kreil, D.P.; Dong, C.; Yamazaki, T.; Zlabinger, G.; et al. B7-H3 is a potent inhibitor of human T-cell activation: No evidence for B7-H3 and TREML2 interaction. Eur. J. Immunol. 2009, 39, 1754-1764. [CrossRef]

98. Yan, R.; Yang, S.; Gu, A.; Zhan, F.; He, C.; Qin, C.; Zhang, X.; Feng, P. Murine b7-h3 is a co-stimulatory molecule for T cell activation. Monoclon. Antibodies Immunodiagn. Immunother. 2013, 32, 395-398. [CrossRef]

99. Vigdorovich, V.; Ramagopal, U.A.; Lázár-Molnár, E.; Sylvestre, E.; Lee, J.S.; Hofmeyer, K.A.; Zang, X.; Nathenson, S.G.; Almo, S.C. Structure and T cell inhibition properties of B7 family member, B7-H3. Structure 2013, 21, 707-717. [CrossRef] [PubMed]

100. Ahmed, M.; Cheng, M.; Zhao, Q.; Goldgur, Y.; Cheal, S.M.; Guo, H.F.; Larson, S.M.; Cheung, N.K. Humanized affinity-matured monoclonal antibody $8 \mathrm{H} 9$ has potent antitumor activity and binds to FG loop of tumor antigen B7-H3. J. Biol. Chem. 2015, 290, 30018-30029. [CrossRef]

101. Loo, D.; Alderson, R.F.; Chen, F.Z.; Huang, L.; Zhang, W.; Gorlatov, S.; Burke, S.; Ciccarone, V.; Li, H.; Yang, Y.; et al. Development of an Fc-enhanced anti-B7-H3 monoclonal antibody with potent antitumor activity. Clin. Cancer Res. Off. J. Am. Assoc. Cancer Res. 2012, 18, 3834-3845. [CrossRef]

102. Wu, C.P.; Jiang, J.T.; Tan, M.; Zhu, Y.B.; Ji, M.; Xu, K.F.; Zhao, J.M.; Zhang, G.B.; Zhang, X.G. Relationship between co-stimulatory molecule B7-H3 expression and gastric carcinoma histology and prognosis. World J. Gastroenterol. 2006, 12, 457-459. [CrossRef] [PubMed]

103. Dai, W.; Shen, G.; Qiu, J.; Zhao, X.; Gao, Q. Aberrant expression of B7-H3 in gastric adenocarcinoma promotes cancer cell metastasis. Oncol. Rep. 2014, 32, 2086-2092. [CrossRef]

104. Li, Y.; Yang, X.; Wu, Y.; Zhao, K.; Ye, Z.; Zhu, J.; Xu, X.; Zhao, X.; Xing, C. B7-H3 promotes gastric cancer cell migration and invasion. Oncotarget 2017, 8, 71725-71735. [CrossRef]

105. Li, Z.-Y.; Wang, J.-T.; Chen, G.; Shan, Z.-G.; Wang, T.-T.; Shen, Y.; Chen, J.; Yan, Z.-B.; Peng, L.-S.; Mao, F.-Y.; et al. Expression, regulation and clinical significance of B7-H3 on neutrophils in human gastric cancer. Clin. Immunol. 2021, 227, 108753. [CrossRef]

106. Zhan, S.; Liu, Z.; Zhang, M.; Guo, T.; Quan, Q.; Huang, L.; Guo, L.; Cao, L.; Zhang, X. Overexpression of B7-H3 in $\alpha$-SMA-positive fibroblasts is associated with cancer progression and survival in gastric adenocarcinomas. Front. Oncol. 2020, 9, 1466. [CrossRef]

107. Li, Y.; Yang, X.; Yao, P.; Shen, W.; Wu, Y.; Ye, Z.; Zhao, K.; Chen, H.; Cao, J.; Xing, C. B7-H3 increases the radioresistance of gastric cancer cells through regulating baseline levels of cell autophagy. Am. J. Transl. Res. 2019, 11, 4438-4449. [PubMed]

108. Ulase, D.; Behrens, H.-M.; Krueger, S.; Zeissig, S.; Röcken, C. Gastric carcinomas with stromal B7-H3 expression have lower intratumoural CD8+ T cell density. Int. J. Mol. Sci. 2021, 22, 2129. [CrossRef] [PubMed]

109. Prasad, D.V.; Richards, S.; Mai, X.M.; Dong, C. B7S1, a novel B7 family member that negatively regulates T cell activation. Immunity 2003, 18, 863-873. [CrossRef]

110. Sica, G.L.; Choi, I.H.; Zhu, G.; Tamada, K.; Wang, S.D.; Tamura, H.; Chapoval, A.I.; Flies, D.B.; Bajorath, J.; Chen, L. B7-H4, a molecule of the B7 family, negatively regulates T cell immunity. Immunity 2003, 18, 849-861. [CrossRef] 
111. Zang, X.; Loke, P.; Kim, J.; Murphy, K.; Waitz, R.; Allison, J.P. B7x: A widely expressed B7 family member that inhibits T cell activation. Proc. Natl. Acad. Sci. USA 2003, 100, 10388-10392. [CrossRef] [PubMed]

112. Choi, I.H.; Zhu, G.; Sica, G.L.; Strome, S.E.; Cheville, J.C.; Lau, J.S.; Zhu, Y.; Flies, D.B.; Tamada, K.; Chen, L. Genomic organization and expression analysis of B7-H4, an immune inhibitory molecule of the B7 family. J. Immunol. 2003, 171, 4650-4654. [CrossRef]

113. Watanabe, N.; Gavrieli, M.; Sedy, J.R.; Yang, J.; Fallarino, F.; Loftin, S.K.; Hurchla, M.A.; Zimmerman, N.; Sim, J.; Zang, X.; et al. BTLA is a lymphocyte inhibitory receptor with similarities to CTLA-4 and PD-1. Nat. Immunol. 2003, 4, 670-679. [CrossRef]

114. Sedy, J.R.; Gavrieli, M.; Potter, K.G.; Hurchla, M.A.; Lindsley, R.C.; Hildner, K.; Scheu, S.; Pfeffer, K.; Ware, C.F.; Murphy, T.L.; et al. $\mathrm{B}$ and $\mathrm{T}$ lymphocyte attenuator regulates $\mathrm{T}$ cell activation through interaction with herpesvirus entry mediator. Nat. Immunol. 2005, 6, 90-98. [CrossRef]

115. Arigami, T.; Uenosono, Y.; Hirata, M.; Hagihara, T.; Yanagita, S.; Ishigami, S.; Natsugoe, S. Expression of B7-H4 in blood of patients with gastric cancer predicts tumor progression and prognosis. J. Surg. Oncol. 2010, 102, 748-752. [CrossRef]

116. Cao, Q.; Wang, Y.; Zheng, D.; Sun, Y.; Wang, Y.; Lee, V.W.; Zheng, G.; Tan, T.K.; Ince, J.; Alexander, S.I.; et al. IL-10/TGF-betamodified macrophages induce regulatory T cells and protect against adriamycin nephrosis. J. Am. Soc. Nephrol. JASN 2010, 21, 933-942. [CrossRef]

117. Kryczek, I.; Zou, L.; Rodriguez, P.; Zhu, G.; Wei, S.; Mottram, P.; Brumlik, M.; Cheng, P.; Curiel, T.; Myers, L.; et al. B7-H4 expression identifies a novel suppressive macrophage population in human ovarian carcinoma. J. Exp. Med. 2006, 203, 871-881. [CrossRef]

118. Kryczek, I.; Wei, S.; Zou, L.; Zhu, G.; Mottram, P.; Xu, H.; Chen, L.; Zou, W. Cutting edge: Induction of B7-H4 on APCs through IL-10: Novel suppressive mode for regulatory T cells. J. Immunol. 2006, 177, 40-44. [CrossRef]

119. Rahbar, R.; Lin, A.; Ghazarian, M.; Yau, H.L.; Paramathas, S.; Lang, P.A.; Schildknecht, A.; Elford, A.R.; Garcia-Batres, C.; Martin, B.; et al. B7-H4 expression by nonhematopoietic cells in the tumor microenvironment promotes antitumor immunity. Cancer Immunol. Res. 2015, 3, 184-195. [CrossRef] [PubMed]

120. Dangaj, D.; Lanitis, E.; Zhao, A.; Joshi, S.; Cheng, Y.; Sandaltzopoulos, R.; Ra, H.J.; Danet-Desnoyers, G.; Powell, D.J., Jr.; Scholler, $\mathrm{N}$. Novel recombinant human b7-h4 antibodies overcome tumoral immune escape to potentiate T-cell antitumor responses. Cancer Res. 2013, 73, 4820-4829. [CrossRef]

121. Salceda, S.; Tang, T.; Kmet, M.; Munteanu, A.; Ghosh, M.; Macina, R.; Liu, W.; Pilkington, G.; Papkoff, J. The immunomodulatory protein B7-H4 is overexpressed in breast and ovarian cancers and promotes epithelial cell transformation. Exp. Cell Res. 2005, 306, 128-141. [CrossRef] [PubMed]

122. Zhou, L.; Ruan, M.; Liu, Y.; Zhu, Y.; Fu, D.; Wu, K.; Zhang, Q. B7H4 expression in tumor cells impairs CD8 T cell responses and tumor immunity. Cancer Immunol. Immunother. 2020, 69, 163-174. [CrossRef] [PubMed]

123. Jiang, J.; Zhu, Y.; Wu, C.; Shen, Y.; Wei, W.; Chen, L.; Zheng, X.; Sun, J.; Lu, B.; Zhang, X. Tumor expression of B7-H4 predicts poor survival of patients suffering from gastric cancer. Cancer Immunol. Immunother. 2010, 59, 1707-1714. [CrossRef] [PubMed]

124. Shan, Z.-G.; Yan, Z.-B.; Peng, L.-S.; Cheng, P.; Teng, Y.-S.; Mao, F.-Y.; Fan, K.; Zhuang, Y.; Zhao, Y.-L. Granulocyte-macrophage colony-stimulating factor-activated neutrophils express B7-H4 that correlates with gastric cancer progression and poor patient survival. J. Immunol. Res. 2021, 2021, 6613247. [CrossRef] [PubMed]

125. Cui, Y.; Li, Z. B7-H4 is predictive of poor prognosis in patients with gastric cancer. Med. Sci. Monit. 2016, 22, 4233-4237. [CrossRef] [PubMed]

126. Zhou, D.; Zhou, Y.; Li, C.; Yang, L. Silencing of B7-H4 suppresses the tumorigenicity of the MGC-803 human gastric cancer cell line and promotes cell apoptosis via the mitochondrial signaling pathway. Int. J. Oncol. 2018, 52, 1267-1276. [CrossRef]

127. Arigami, T.; Uenosono, Y.; Ishigami, S.; Hagihara, T.; Haraguchi, N.; Natsugoe, S. Clinical significance of the B7-H4 coregulatory molecule as a novel prognostic marker in gastric cancer. World J. Surg. 2011, 35, 2051. [CrossRef] [PubMed]

128. Maskey, N.; Li, K.; Hu, M.; Xu, Z.; Peng, C.; Yu, F.; Cao, H.; Chen, J.; Li, Y.; Yang, G. Impact of neoadjuvant chemotherapy on lymphocytes and co-inhibitory B7-H4 molecule in gastric cancer: Low B7-H4 expression associates with favorable prognosis. Tumour Biol. J. Int. Soc. Oncodev. Biol. Med. 2014, 35, 11837-11843. [CrossRef]

129. Deng, J.; Le Mercier, I.; Kuta, A.; Noelle, R.J. A New VISTA on combination therapy for negative checkpoint regulator blockade. J. ImmunoTher. Cancer 2016, 4, 86. [CrossRef]

130. Huang, X.; Zhang, X.; Li, E.; Zhang, G.; Wang, X.; Tang, T.; Bai, X.; Liang, T. VISTA: An immune regulatory protein checking tumor and immune cells in cancer immunotherapy. J. Hematol. Oncol. 2020, 13, 83. [CrossRef]

131. Mehta, N.; Maddineni, S.; Mathews, I.I.; Sperberg, A.P.; Huang, P.-S.; Cochran, J.R. Structure and functional binding epitope of V-domain Ig suppressor of T-cell activation (VISTA). bioRxiv 2019, 597716. [CrossRef]

132. Liu, H.; Tekle, C.; Chen, Y.W.; Kristian, A.; Zhao, Y.; Zhou, M.; Liu, Z.; Ding, Y.; Wang, B.; Mælandsmo, G.M.; et al. B7-H3 silencing increases paclitaxel sensitivity by abrogating Jak2/Stat3 phosphorylation. Mol. Cancer Ther. 2011, 10, 960-971. [CrossRef]

133. Le Mercier, I.; Chen, W.; Lines, J.L.; Day, M.; Li, J.; Sergent, P.; Noelle, R.J.; Wang, L. VISTA Regulates the development of protective antitumor immunity. Cancer Res. 2014, 74, 1933-1944. [CrossRef] [PubMed]

134. Borggrewe, M.; Grit, C.; Den Dunnen, W.F.A.; Burm, S.M.; Bajramovic, J.J.; Noelle, R.J.; Eggen, B.J.L.; Laman, J.D. VISTA expression by microglia decreases during inflammation and is differentially regulated in CNS diseases. Glia 2018, 66, 2645-2658. [CrossRef] [PubMed]

135. ElTanbouly, M.A.; Croteau, W.; Noelle, R.J.; Lines, J.L. VISTA: A novel immunotherapy target for normalizing innate and adaptive immunity. Semin. Immunol. 2019, 42, 101308. [CrossRef] 
136. Yoon, K.W.; Byun, S.; Kwon, E.; Hwang, S.Y.; Chu, K.; Hiraki, M.; Jo, S.H.; Weins, A.; Hakroush, S.; Cebulla, A.; et al. Control of signaling-mediated clearance of apoptotic cells by the tumor suppressor p53. Science 2015, 349, 1261669. [CrossRef] [PubMed]

137. Deng, J.; Li, J.; Sarde, A.; Lines, J.L.; Lee, Y.C.; Qian, D.C.; Pechenick, D.A.; Manivanh, R.; Le Mercier, I.; Lowrey, C.H.; et al. Hypoxia-induced VISTA promotes the suppressive function of myeloid-derived suppressor cells in the tumor microenvironment. Cancer Immunol. Res. 2019, 7, 1079-1090. [CrossRef]

138. ElTanbouly, M.A.; Schaafsma, E.; Noelle, R.J.; Lines, J.L. VISTA: Coming of age as a multi-lineage immune checkpoint. Clin. Exp. Immunol. 2020, 200, 120-130. [CrossRef]

139. Nowak, E.C.; Lines, J.L.; Varn, F.S.; Deng, J.; Sarde, A.; Mabaera, R.; Kuta, A.; Le Mercier, I.; Cheng, C.; Noelle, R.J. Immunoregulatory functions of VISTA. Immunol. Rev. 2017, 276, 66-79. [CrossRef]

140. Flies, D.B.; Han, X.; Higuchi, T.; Zheng, L.; Sun, J.; Ye, J.J.; Chen, L. Coinhibitory receptor PD-1H preferentially suppresses CD4 ${ }^{+}$ T cell-mediated immunity. J. Clin. Investig. 2014, 124, 1966-1975. [CrossRef]

141. Wang, J.; Wu, G.; Manick, B.; Hernandez, V.; Renelt, M.; Erickson, C.; Guan, J.; Singh, R.; Rollins, S.; Solorz, A.; et al. VSIG-3 as a ligand of VISTA inhibits human T-cell function. Immunology 2019, 156, 74-85. [CrossRef]

142. Johnston, R.J.; Su, L.J.; Pinckney, J.; Critton, D.; Boyer, E.; Krishnakumar, A.; Corbett, M.; Rankin, A.L.; Dibella, R.; Campbell, L.; et al. VISTA is an acidic pH-selective ligand for PSGL-1. Nature 2019, 574, 565-570. [CrossRef]

143. Liu, J.; Yuan, Y.; Chen, W.; Putra, J.; Suriawinata, A.A.; Schenk, A.D.; Miller, H.E.; Guleria, I.; Barth, R.J.; Huang, Y.H.; et al. Immune-checkpoint proteins VISTA and PD-1 nonredundantly regulate murine T-cell responses. Proc. Natl. Acad. Sci. USA 2015, 112, 6682-6687. [CrossRef]

144. Hu, C.; Xu, Z.; Chen, S.; Lv, H.; Wang, Y.; Wang, X.; Mo, S.; Shi, C.; Wei, S.; Hu, L.; et al. Overexpression of B7H5/CD28H is associated with worse survival in human gastric cancer. J. Cell. Mol. Med. 2020, 24, 1360-1369. [CrossRef]

145. Oliveira, P.; Carvalho, J.; Rocha, S.; Azevedo, M.; Reis, I.; Camilo, V.; Sousa, B.; Valente, S.; Paredes, J.; Almeida, R.; et al. Dies1/VISTA expression loss is a recurrent event in gastric cancer due to epigenetic regulation. Sci. Rep. 2016, 6, 34860. [CrossRef]

146. Böger, C.; Behrens, H.-M.; Krüger, S.; Röcken, C. The novel negative checkpoint regulator VISTA is expressed in gastric carcinoma and associated with PD-L1/PD-1: A future perspective for a combined gastric cancer therapy? Oncoimmunology 2017, 6, e1293215. [CrossRef]

147. Brandt, C.S.; Baratin, M.; Yi, E.C.; Kennedy, J.; Gao, Z.; Fox, B.; Haldeman, B.; Ostrander, C.D.; Kaifu, T.; Chabannon, C.; et al. The B7 family member B7-H6 is a tumor cell ligand for the activating natural killer cell receptor NKp30 in humans. J. Exp. Med. 2009, 206, 1495-1503. [CrossRef]

148. Kaifu, T.; Escalière, B.; Gastinel, L.N.; Vivier, E.; Baratin, M. B7-H6/NKp30 interaction: A mechanism of alerting NK cells against tumors. Cell. Mol. Life Sci. CMLS 2011, 68, 3531-3539. [CrossRef] [PubMed]

149. Li, Y.; Wang, Q.; Mariuzza, R.A. Structure of the human activating natural cytotoxicity receptor NKp30 bound to its tumor cell ligand B7-H6. J. Exp. Med. 2011, 208, 703-714. [CrossRef]

150. Matta, J.; Baratin, M.; Chiche, L.; Forel, J.M.; Cognet, C.; Thomas, G.; Farnarier, C.; Piperoglou, C.; Papazian, L.; Chaussabel, D.; et al. Induction of B7-H6, a ligand for the natural killer cell-activating receptor NKp30, in inflammatory conditions. Blood 2013, 122, 394-404. [CrossRef] [PubMed]

151. Wu, F.; Wang, J.; Ke, X. Knockdown of B7-H6 inhibits tumor progression and enhances chemosensitivity in B-cell non-Hodgkin lymphoma. Int. J. Oncol. 2016, 48, 1561-1570. [CrossRef] [PubMed]

152. Che, F.; Xie, X.; Wang, L.; Su, Q.; Jia, F.; Ye, Y.; Zang, L.; Wang, J.; Li, H.; Quan, Y.; et al. B7-H6 expression is induced by lipopolysaccharide and facilitates cancer invasion and metastasis in human gliomas. Int. Immunopharmacol. 2018, 59, 318-327. [CrossRef] [PubMed]

153. Hu, Y.; Zeng, T.; Xiao, Z.; Hu, Q.; Li, Y.; Tan, X.; Yue, H.; Wang, W.; Tan, H.; Zou, J. Immunological role and underlying mechanisms of B7-H6 in tumorigenesis. Clin. Chim. Acta 2020, 502, 191-198. [CrossRef]

154. Cao, G.; Wang, J.; Zheng, X.; Wei, H.; Tian, Z.; Sun, R. Tumor therapeutics work as stress inducers to enhance tumor sensitivity to natural killer (NK) cell cytolysis by up-regulating NKp30 ligand B7-H6. J. Biol. Chem. 2015, 290, 29964-29973. [CrossRef] [PubMed]

155. Xu, X.; Narni-Mancinelli, E.; Cantoni, C.; Li, Y.; Guia, S.; Gauthier, L.; Chen, Q.; Moretta, A.; Vély, F.; Eisenstein, E.; et al. Structural insights into the inhibitory mechanism of an antibody against B7-H6, a stress-induced cellular ligand for the natural killer cell receptor NKp30. J. Mol. Biol. 2016, 428, 4457-4466. [CrossRef] [PubMed]

156. Gacerez, A.T.; Hua, C.K.; Ackerman, M.E.; Sentman, C.L. Chimeric antigen receptors with human scFvs preferentially induce T cell anti-tumor activity against tumors with high B7H6 expression. Cancer Immunol. Immunother. 2018, 67, 749-759. [CrossRef] [PubMed]

157. Chen, X.-J.; Shen, J.; Zhang, G.-B.; Chen, W.-C. B7-H6 protein expression has no prognostic significance in human gastric carcinoma. Pathol. Oncol. Res. 2014, 20, 203-207. [CrossRef]

158. Li, D.; Xiang, S.; Shen, J.; Xiao, M.; Zhao, Y.; Wu, X.; Du, F.; Ji, H.; Li, M.; Zhao, Q.; et al. Comprehensive understanding of B7 family in gastric cancer: Expression profile, association with clinicopathological parameters and downstream targets. Int. J. Biol. Sci. 2020, 16, 568-582. [CrossRef]

159. Janakiram, M.; Chinai, J.M.; Fineberg, S.; Fiser, A.; Montagna, C.; Medavarapu, R.; Castano, E.; Jeon, H.; Ohaegbulam, K.C.; Zhao, R.; et al. Expression, clinical significance, and receptor identification of the newest B7 family member HHLA2 protein. Clin. Cancer Res. Off. J. Am. Assoc. Cancer Res. 2015, 21, 2359-2366. [CrossRef] 
160. Mager, D.L.; Hunter, D.G.; Schertzer, M.; Freeman, J.D. Endogenous retroviruses provide the primary polyadenylation signal for two new human genes (HHLA2 and HHLA3). Genomics 1999, 59, 255-263. [CrossRef]

161. Zhao, R.; Chinai, J.M.; Buhl, S.; Scandiuzzi, L.; Ray, A.; Jeon, H.; Ohaegbulam, K.C.; Ghosh, K.; Zhao, A.; Scharff, M.D.; et al. HHLA2 is a member of the B7 family and inhibits human CD4 and CD8 T-cell function. Proc. Natl. Acad. Sci. USA 2013, 110, 9879-9884. [CrossRef]

162. Flajnik, M.F.; Tlapakova, T.; Criscitiello, M.F.; Krylov, V.; Ohta, Y. Evolution of the B7 family: Co-evolution of B7H6 and NKp30, identification of a new B7 family member, B7H7, and of B7's historical relationship with the MHC. Immunogenetics 2012, 64, 571-590. [CrossRef] [PubMed]

163. Zhu, Y.; Yao, S.; Iliopoulou, B.P.; Han, X.; Augustine, M.M.; Xu, H.; Phennicie, R.T.; Flies, S.J.; Broadwater, M.; Ruff, W.; et al. B7-H5 costimulates human T cells via CD28H. Nat. Commun. 2013, 4, 2043. [CrossRef] [PubMed]

164. Xiao, Y.; Freeman, G.J. A new B7:CD28 family checkpoint target for cancer immunotherapy: HHLA2. Clin. Cancer Res. Off. J. Am. Assoc. Cancer Res. 2015, 21, 2201-2203. [CrossRef]

165. Janakiram, M.; Chinai, J.M.; Zhao, A.; Sparano, J.A.; Zang, X. HHLA2 and TMIGD2: New immunotherapeutic targets of the B7 and CD28 families. Oncoimmunology 2015, 4, e1026534. [CrossRef] [PubMed]

166. Shimonosono, M.; Arigami, T.; Yanagita, S.; Matsushita, D.; Uchikado, Y.; Kijima, Y.; Kurahara, H.; Kita, Y.; Mori, S.; Sasaki, K.; et al. The association of human endogenous retrovirus-H long terminal repeat-associating protein 2 (HHLA2) expression with gastric cancer prognosis. Oncotarget 2018, 9, 22069-22078. [CrossRef]

167. Wei, L.; Tang, L.; Chang, H.; Huo, S.; Li, Y. HHLA2 overexpression is a novel biomarker of malignant status and poor prognosis in gastric cancer. Hum. Cell 2020, 33, 116-122. [CrossRef]

168. Hecht, I.; Toporik, A.; Podojil, J.R.; Vaknin, I.; Cojocaru, G.; Oren, A.; Aizman, E.; Liang, S.C.; Leung, L.; Dicken, Y.; et al. ILDR2 is a novel B7-like protein that negatively regulates T cell responses. J. Immunol. 2018, 200, 2025-2037. [CrossRef]

169. Dokmanovic-Chouinard, M.; Chung, W.K.; Chevre, J.-C.; Watson, E.; Yonan, J.; Wiegand, B.; Bromberg, Y.; Wakae, N.; Wright, C.V.; Overton, J.; et al. Positional cloning of "Lisch-like", a candidate modifier of susceptibility to type 2 diabetes in mice. PLoS Genet. 2008, 4, e1000137. [CrossRef] [PubMed]

170. Higashi, T.; Tokuda, S.; Kitajiri, S.; Masuda, S.; Nakamura, H.; Oda, Y.; Furuse, M. Analysis of the 'angulin' proteins LSR, ILDR1 and ILDR2-tricellulin recruitment, epithelial barrier function and implication in deafness pathogenesis. J. Cell Sci. 2013, 126, 966-977. [CrossRef] [PubMed]

171. Podojil, J.R.; Hecht, I.; Chiang, M.Y.; Vaknin, I.; Barbiro, I.; Novik, A.; Neria, E.; Rotman, G.; Miller, S.D. ILDR2-Fc is a novel regulator of immune homeostasis and inducer of antigen-specific immune tolerance. J. Immunol. 2018, 200, 2013-2024. [CrossRef]

172. Huetter, J.; Gritzan, U.; Gutcher, I.; Doecke, W.-D.; Luetke-Eversloh, M.V.; Golfier, S.; Roider, H.G.; Frisk, A.-L.; Hunter, J.; Pow, A.; et al. Characterization of BAY 1905254, an immune checkpoint inhibitor targeting the immunoglobulin-like domain containing receptor 2 (ILDR2). Cancer Immunol. Res. 2020, 8, 895-911. [CrossRef]

173. Lipson, E.J.; Drake, C.G. Ipilimumab: An anti-CTLA-4 antibody for metastatic melanoma. Clin. Cancer Res. Off. J. Am. Assoc. Cancer Res. 2011, 17, 6958-6962. [CrossRef]

174. Wang, B.; Qin, L.; Ren, M.; Sun, H. Effects of combination of anti-CTLA-4 and anti-PD-1 on gastric cancer cells proliferation, apoptosis and metastasis. Cell. Physiol. Biochem. Int. J. Exp. Cell. Physiol. Biochem. Pharmacol. 2018, 49, 260-270. [CrossRef] [PubMed]

175. Ralph, C.; Elkord, E.; Burt, D.J.; O’Dwyer, J.F.; Austin, E.B.; Stern, P.L.; Hawkins, R.E.; Thistlethwaite, F.C. Modulation of lymphocyte regulation for cancer therapy: A phase II trial of tremelimumab in advanced gastric and esophageal adenocarcinoma. Clin. Cancer Res. Off. J. Am. Assoc. Cancer Res. 2010, 16, 1662-1672. [CrossRef]

176. Janjigian, Y.Y.; Ott, P.A.; Calvo, E.; Kim, J.W.; Ascierto, P.A.; Sharma, P.; Peltola, K.J.; Jaeger, D.; Evans, T.R.J.; De Braud, F.G.; et al. Nivolumab \pm ipilimumab in pts with advanced (adv)/metastatic chemotherapy-refractory (CTx-R) gastric (G), esophageal (E), or gastroesophageal junction (GEJ) cancer: CheckMate 032 study. J. Clin. Oncol. 2017, 35, 4014. [CrossRef]

177. Muro, K.; Chung, H.C.; Shankaran, V.; Geva, R.; Catenacci, D.; Gupta, S.; Eder, J.P.; Golan, T.; Le, D.T.; Burtness, B.; et al. Pembrolizumab for patients with PD-L1-positive advanced gastric cancer (KEYNOTE-012): A multicentre, open-label, phase 1b trial. Lancet. Oncol. 2016, 17, 717-726. [CrossRef]

178. Kang, Y.-K.; Boku, N.; Satoh, T.; Ryu, M.-H.; Chao, Y.; Kato, K.; Chung, H.; Chen, J.-S.; Muro, K.; Kang, W.; et al. Nivolumab in patients with advanced gastric or gastro-oesophageal junction cancer refractory to, or intolerant of, at least two previous chemotherapy regimens (ONO-4538-12, ATTRACTION-2): A randomised, double-blind, placebo-controlled, phase 3 trial. Lancet 2017, 390, 2461-2471. [CrossRef]

179. Tabernero, J.; Van Cutsem, E.; Bang, Y.-J.; Fuchs, C.S.; Wyrwicz, L.; Lee, K.W.; Kudaba, I.; Garrido, M.; Chung, H.C.; Castro Salguero, H.R. Pembrolizumab with or without chemotherapy versus chemotherapy for advanced gastric or gastroesophageal junction (G/GEJ) adenocarcinoma: The phase III KEYNOTE-062 study. J. Clin. Oncol. 2019, 37, LBA4007. [CrossRef]

180. Chung, H.C.; Arkenau, H.-T.; Lee, J.; Rha, S.Y.; Oh, D.-Y.; Wyrwicz, L.; Kang, Y.-K.; Lee, K.-W.; Bauer, T.M.; Lee, S.S.; et al. Abstract CT111: Avelumab (anti-PD-L1) as first-line maintenance (1L mn) or second-line $(2 \mathrm{~L})$ therapy in patients with advanced gastric or gastroesophageal junction cancer (GC/GEJC): Updated phase Ib results from the JAVELIN Solid Tumor trial. Cancer Res. 2018, 78, CT111. [CrossRef] 
181. Ohtsu, A.; Tabernero, J.; Bang, Y.-J.; Fuchs, C.S.; Sun, L.; Wang, Z.; Csiki, I.; Koshiji, M.; Van Cutsem, E. Pembrolizumab (MK-3475) versus paclitaxel as second-line therapy for advanced gastric or gastroesophageal junction (GEJ) adenocarcinoma: Phase 3 KEYNOTE-061 study. J. Clin. Oncol. 2016, 34, TPS183. [CrossRef]

182. Fuchs, C.S.; Doi, T.; Jang, R.W.; Muro, K.; Satoh, T.; Machado, M.; Sun, W.; Jalal, S.I.; Shah, M.A.; Metges, J.-P.; et al. Safety and Efficacy of pembrolizumab monotherapy in patients with previously treated advanced gastric and gastroesophageal junction cancer: Phase 2 clinical KEYNOTE-059 trial. JAMA Oncol. 2018, 4, e180013. [CrossRef]

183. Bang, Y.J.; Ruiz, E.Y.; Van Cutsem, E.; Lee, K.W.; Wyrwicz, L.; Schenker, M.; Alsina, M.; Ryu, M.H.; Chung, H.C.; Evesque, L.; et al. Phase III, randomised trial of avelumab versus physician's choice of chemotherapy as third-line treatment of patients with advanced gastric or gastro-oesophageal junction cancer: Primary analysis of JAVELIN Gastric 300. Ann. Oncol. 2018, 29, 2052-2060. [CrossRef] [PubMed]

184. Chen, C.; Zhang, F.; Zhou, N.; Gu, Y.-M.; Zhang, Y.-T.; He, Y.-D.; Wang, L.; Yang, L.-X.; Zhao, Y.; Li, Y.-M. Efficacy and safety of immune checkpoint inhibitors in advanced gastric or gastroesophageal junction cancer: A systematic review and meta-analysis. Oncoimmunology 2019, 8, e1581547. [CrossRef] [PubMed]

185. Marhelava, K.; Pilch, Z.; Bajor, M.; Graczyk-Jarzynka, A.; Zagozdzon, R. Targeting negative and positive immune checkpoints with monoclonal antibodies in therapy of cancer. Cancers 2019, 11, 1756. [CrossRef] [PubMed]

186. Friedman, C.F.; Proverbs-Singh, T.A.; Postow, M.A. Treatment of the immune-related adverse effects of immune checkpoint inhibitors: A review. JAMA Oncol 2016, 2, 1346-1353. [CrossRef] [PubMed]

187. ClinicalTrials.gov. Avelumab in Third-Line Gastric Cancer (JAVELIN Gastric 300). 2020. Available online: https:/ clinicaltrials. gov/ct2/show / NCT02625623 (accessed on 24 November 2020).

188. ClinicalTrials.gov. Avelumab in First-Line Maintenance Gastric Cancer (JAVELIN Gastric 100). 2021. Available online: https: / / clinicaltrials.gov/ct2/show / NCT02625610 (accessed on 24 June 2021).

189. ClinicalTrials.gov. Nivolumab, Ipilimumab and OTSGC-A24 Therapeutic Peptide Vaccine in Gastric Cancer-A Combination Immunotherapy Phase Ib Study (da VINci). 2019. Available online: https:/ / clinicaltrials.gov/ct2/show / NCT03784040 (accessed on 8 April 2019).

190. ClinicalTrials.gov. Checkpoint Inhibitor and Radiotherapy for Recurrent Gastric Cancer (CIRCUIT). 2020. Available online: https: / / clinicaltrials.gov/ct2/show/NCT03453164 (accessed on 15 July 2020).

191. ClinicalTrials.gov. Combination of Nivolumab and Ipilimumab in Breast, Ovarian and Gastric Cancer Patients. 2019. Available online: https: / / clinicaltrials.gov/ct2/show / NCT03342417 (accessed on 31 May 2019).

192. ClinicalTrials.govl. Study of Adjuvant ONO-4538 with Resected Gastric Cancer. 2020. Available online: https://clinicaltrials. gov / ct2/show / NCT03006705 (accessed on 22 September 2021).

193. ClinicalTrials.gov. Postoperative Immunotherapy vs Standard Chemotherapy for Gastric Cancer with High Risk for Recurrence (VESTIGE). 2021. Available online: https:/ / clinicaltrials.gov/ct2/show /NCT03443856 (accessed on 5 February 2021).

194. ClinicalTrials.gov. A Study of Pembrolizumab (MK-3475) in Participants with Recurrent or Metastatic Gastric or Gastroesophageal Junction Adenocarcinoma (MK-3475-059/KEYNOTE-059). 2020. Available online: https://clinicaltrials.gov/ct2/show/NCT023 35411 (accessed on 30 July 2021).

195. ClinicalTrials.gov. Study of Pembrolizumab (MK-3475) as First-Line Monotherapy and Combination Therapy for Treatment of Advanced Gastric or Gastroesophageal Junction Adenocarcinoma (MK-3475-062/KEYNOTE-062). 2021. Available online: https: / / clinicaltrials.gov / ct2/show / NCT02494583 (accessed on 10 March 2021).

196. ClinicalTrials.gov. A Study of DSP-7888 Dosing Emulsion in Combination with Immune Checkpoint Inhibitors in Adult Patients with Advanced Solid Tumors. 2021. Available online: https://clinicaltrials.gov/ct2/show/NCT03311334 (accessed on 10 September 2021).

197. ClinicalTrials.gov. FT500 as Monotherapy and in Combination with Immune Checkpoint Inhibitors in Subjects with Advanced Solid Tumors. 2020. Available online: https:/ / clinicaltrials.gov/ct2/show /NCT03841110 (accessed on 2 November 2020).

198. Mazloom, A.; Ghalehsari, N.; Gazivoda, V.; Nimkar, N.; Paul, S.; Gregos, P.; Rateshwar, J.; Khan, U. Role of immune checkpoint inhibitors in gastrointestinal malignancies. J. Clin. Med. 2020, 9, 2533. [CrossRef] 